Check for updates

Cite this: RSC Adv., 2017, 7, 33385

\title{
Removal of heavy metals with sequential sludge washing techniques using saponin: optimization conditions, kinetics, removal effectiveness, binding intensity, mobility and mechanism
}

\begin{abstract}
Jian Tang, Junguo He, (D)* Tiantian Liu and Xiaodong Xin
Testing of sequential sludge washing in triplicate using typical biosurfactant saponin was conducted to remove heavy metals. The aim of the testing was to improve efficiency and reduce mobility of heavy metals. Different washing conditions such as concentration, contact time, liquid/solid ratio and $\mathrm{pH}$ were optimized. The heavy metal desorption performances were investigated strictly and the experimental data fitted the pseudo-second order equation very well. A sequential washing step and heavy metal mobilization was investigated, and the results demonstrated that the total content and fractions of the heavy metals reached remarkable extraction efficiencies, after three washings, $\mathrm{Cr}$ obtained the highest extraction efficiency (65.00\%), and the $\mathrm{Pb}$ exchangeable fraction acquired the highest extraction efficiency (85.00\%). Also, the heavy metal binding intensity and mobility were investigated, and the results indicated that the heavy metal binding intensity $\left(I_{R}\right)$ increased after washing, conversely, the mobility $\left(M_{F}\right)$ decreased, due to the weak fractions extracted by saponin. The toxicity characteristic leaching procedure (TCLP) indicated that heavy metals have more stable fractions in the after washing sludge. SEM, FTIR and XRD revealed that mechanism of saponin enhanced heavy metal extraction from the sludge, elucidated that carboxyl and hydroxyl were the main functional groups. This study indicated that the saponin may be a replacement for organic acids, inorganic acids and less environmentally friendly refractory chelators in the extraction of heavy metals from the sludge.
\end{abstract}

Received 16th April 2017

Accepted 26th June 2017

DOI: $10.1039 / c 7 r a 04284 a$

rsc.li/rsc-advances food chain through the uptake by plants from soil, and lastly end up in humans. High content of heavy metals in the sludge is one of the most obstacles restricting its agriculture application. ${ }^{4,5}$ Therefore, to obtain the sludge, which heavy metals content meet the agricultural application standard. It is imperative to seek a sludge treatment method that can reduce heavy metals while preserving organic matters and nutrient elements.

Over the past few decades, many approaches for the sludge treatment and disposal have been introduced. These methods include chemical treatments, ion exchange methods, thermal treatments, bioleaching methods, electrokinetics methods, ultrasound-assisted nitric acid methods. ${ }^{4,6-16}$ Especially, the chemical methods have been focused more than others methods by researcher, due to its simple operation processes, the short operation times, and high removal efficiency for heavy metals in the sludge. ${ }^{8}$ Previous studies have indicated that heavy metals extraction efficiency mainly depends on chemical reagent type, contact time, high temperature, low $\mathrm{pH}$, and long contact time could enhance heavy metal extraction., ${ }^{4,12,14-16}$ Various organic acids, inorganic acids and chelating agent have been applied to remove heavy metals from the sludge efficiently. ${ }^{16,17}$ However, a large number of chemical reagent
School of Municipal and Environmental Engineering, Harbin Institute of Technology, No. 73 Huanghe Road, Nangang District, Harbin 150090, PR China. E-mail: junguohe@263.net; Tel: +86045186289099 
dosages and low pH can obtain high removal efficiency, which results in high processing costs and difficulty in $\mathrm{pH}$ adjustment of the treatment sludge. In addition, these reagents may pose secondary pollution through the soil and groundwater, due to their refractory nature. ${ }^{\mathbf{1 8 , 1 9}}$ Therefore, it is necessary to find an environmental friendly reagents take the place of the organic acids, inorganic acids and chelating agent.

Biodegradable and non-toxic extracting agents have been applied to extracted heavy metal, including humic acids, ${ }^{20,21}$ cyclodextrins, ${ }^{22}$ and biosurfactants. ${ }^{23-25}$ Biosurfactants are bioavailable surface-active compounds mainly produced by bacteria, fungi and yeast. ${ }^{26}$ Also, biosurfactants can also be extracted from the metabolites of plants. ${ }^{27}$ The hydrophilic parts of biosurfactants can be polysaccharides, amino acids, carbohydrates, phosphates and cyclic peptide, while these hydrophilic parts are usually composed of aliphatic hydrocarbons. ${ }^{28}$ In comparison with synthetic surfactants, the biosurfactants often have more functional groups and larger molecular structure, which endows biosurfactants with extraordinary surface activity for the extraction hydrophobic organics and heavy metals. ${ }^{29}$ Meanwhile, biosurfactants can form micelles and reduce surface and interfacial tension. Consequently, biosurfactants can effectively solubilize, disperse and desorb both organics and heavy metals. ${ }^{25}$ The biosurfactant have environmental compatibility characteristic, which facilitate the biodegradation of contaminants and promote the selfdegradation of biosurfactants. ${ }^{23,24,29-31}$

Saponin, a class of non ionic biosurfactants derived from plants, this biosurfactant is composed of a hydrophilic glycoside combined with a lipophilic derivative, saponin is a natural product have been used as a detergent. ${ }^{32}$ Saponin was applied to extract heavy metals and hydrophobic organic compounds (HOCs). ${ }^{33}$ Previous studies investigated the saponin can extract heavy metals from contaminated soils. ${ }^{28,32,34}$ However, to the best of our knowledge, few scientific works have been reported the saponin enhance heavy metal removal from the dewatered sludge, which is necessary for fundamental research and actual remediation.

Therefore, the aim of this study was to identify the optimal washing conditions for removal heavy metal from sludge. Four influencing factors, including saponin concentration, contact time, liquid/solid ratio and $\mathrm{pH}$, are considered based on the results of previous theoretical and experimental studies on sludge washing. Kinetic model of heavy metals extraction, heavy metals mobilization, binding intensity and leaching behavior was investigated. Finally, the SEM, FITR and XRD assistant is utilized to conclude the mechanism of saponin enhance extraction heavy metals from the sludge.

\section{Materials and methods}

\subsection{Source of sewage sludge}

Dewatered sludge sample used in this study was taken from the Qun Li Urban Wastewater Treatment Plant (UWWTP), Harbin. The wastewater treatment plant treats both domestic and industrial wastewater with domestic wastewater accounting for $60 \%$ of total wastewater. Dewatered sludge sample was dried in an oven at $105{ }^{\circ} \mathrm{C}$ for $24 \mathrm{~h}$, the water content is $81.25 \pm 5.21 \%$, then ground and sieved to a size less than $74 \mu \mathrm{m}$, the treated sludge sample was collected and stored in desiccators at room temperature.

Table 1 demonstrated heavy metals contents of the sludge sample collected after detailed characterization. The $\mathrm{Zn}$ and $\mathrm{Cu}$ concentrations were $731.58 \pm 8.98$ and $1352.11 \pm 11.21 \mathrm{mg}$ $\mathrm{kg}^{-1}$, respectively, both of which exceed the control standards for pollutants in sludge from agricultural use (GB 4284-84) and the environmental quality standard for soils (GB 15618-1995). The sludge would lead to heavy metal contaminations without removal heavy metals, such as accumulate in the soil, damage human health and destroy ecosystem. Consider the heavy metals accumulation in the environment and agriculture land, therefore, the six heavy metals ( $\mathrm{Cu}, \mathrm{Zn}, \mathrm{Cr}, \mathrm{Pb}, \mathrm{Ni}, \mathrm{Mn})$ were investigated in this work.

\subsection{Saponin characteristics}

Saponin was purchased from Shanghai Ryon Biological Technology CO., Ltd in this experiment. It is primarily composed of mixture of triterpene glycosides separated from the bark of the tree Quillaja saponaria. The triterpene portion of saponin backbone chain, the maximum sapogenin $\left(\mathrm{C}_{30} \mathrm{H}_{46} \mathrm{O}_{5}\right)$ content was $25 \%$, and the functional group is the hydrophilic portion, which is composed of sugar chains. The critical micelle concentration (CMC) and minimal surface tension of saponin were $57.21 \pm 8.35 \mathrm{mg} \mathrm{L}^{-1}$ and $37.12 \pm 5.78 \mathrm{mN} \mathrm{m}^{-1}$ by the ring method at room temperature. The saponin chemical structure was shown in Fig. $1,^{35}$ chemical structure of saponin molecules

Table 1 Heavy metals contents in the sludge compared to Chinese legal standard ${ }^{a}$

\begin{tabular}{lclll}
\hline Parameters (unit) & Value & Environmental soils ${ }^{b}$ & ${\text { Acid soil }(\mathrm{pH}<6.5)^{c}}^{c}$ & ${\text { Alkaline soil }(\mathrm{pH} \geq 6.5)^{c}}^{c}$ \\
\hline $\mathrm{Cu}\left(\mathrm{mg} \mathrm{kg}^{-1}\right)$ & $1352.11 \pm 11.21$ & 400 & 250 & 500 \\
$\mathrm{Zn}\left(\mathrm{mg} \mathrm{kg}^{-1}\right)$ & $731.58 \pm 8.98$ & 500 & 500 & 1000 \\
$\mathrm{Cr}\left(\mathrm{mg} \mathrm{kg}^{-1}\right)$ & $202.52 \pm 6.27$ & 300 & 600 & 1000 \\
$\mathrm{~Pb}\left(\mathrm{mg} \mathrm{kg}^{-1}\right)$ & $52.50 \pm 6.52$ & 300 & 300 & 1000 \\
$\mathrm{Ni}\left(\mathrm{mg} \mathrm{kg}^{-1}\right)$ & $175.11 \pm 4.12$ & 200 & 100 & 200 \\
$\mathrm{Mn}\left(\mathrm{mg} \mathrm{kg}^{-1}\right)$ & $1033.33 \pm 25.22$ & - & - & -
\end{tabular}

$a$ “_”: not mentioned. ${ }^{b}$ National Standard of the People's Republic of China GB 15618-1995: environmental quality standard for soils. ${ }^{c}$ National Standard of the People's Republic of China GB 4284-84: control standards for pollutants in sludges from agricultural use. 


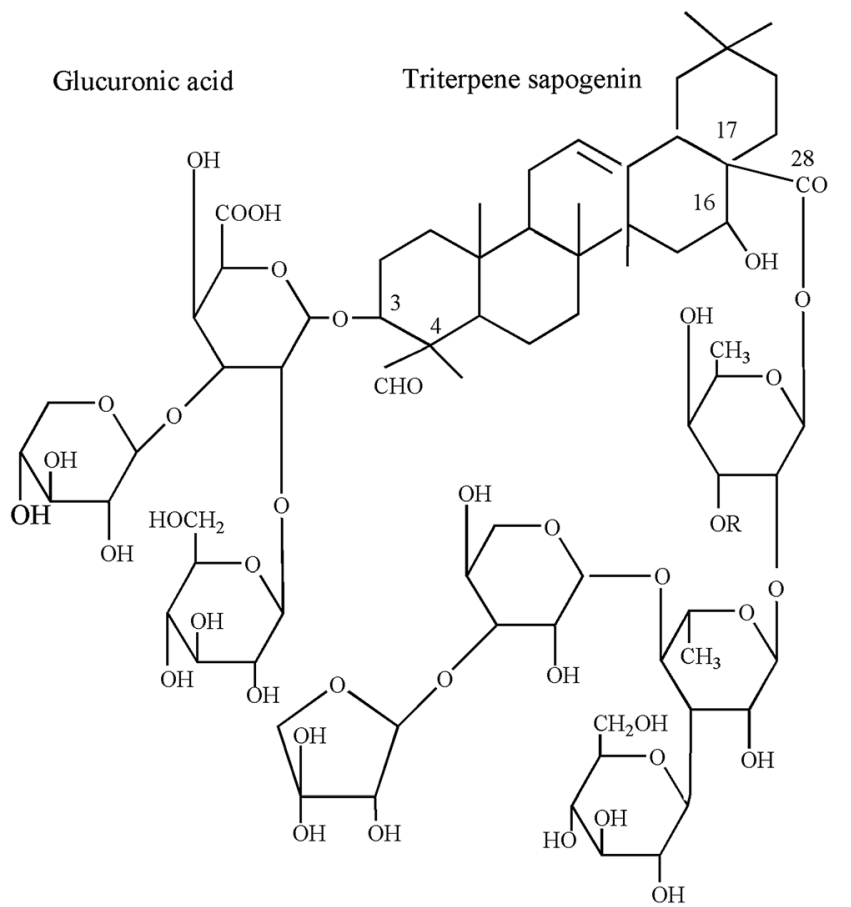

Fig. 1 Chemical structure of saponin

contains one hydrophobic fused-ring of triterpenes, which do not contain the long hydrophobic tail of traditional surfactants, straight hydrocarbon chain. A molecular weight of 1650 was assumed to represent this molecule. ${ }^{36}$ Two hydrophilic sugar chains containing various functional groups are connected to the two ends, C-3 and C-28 of the hydrophobic triterpene backbone, in which one end carries $\beta$-D-glucuronic acid with anionic carboxyl group and the other end carries nonionic glycoside groups when dissolves in water. ${ }^{35}$

\subsection{Sludge washing experiments}

2.3.1. Single-factor condition optimization experiments. Four sets of experiments (tests A, B, C and D) were conducted to examine the effect of influencing factors on heavy metal removal using saponin. Factors were tested using the following sequence: concentration, contact time, liquid/solid ratio and pH. The parameter were shown in Table 2. Heavy metal extraction experiments were carried out in $50 \mathrm{~mL}$ polyethylene centrifuge tubes. When one factor was tested with different values, the other factors remained constant. The optimal condition was identified based on high extraction efficiency and cost effectiveness (e.g. dosage expense and electric charge).

2.3.2. Sequential sludge washing experiments. For each experiment, sludge sample $(0.5 \mathrm{~g})$ in saponin solution, batch heavy metals extraction tests were conducted at a liquid (volume)/ solid (mass) ratio which according to the designed ratio. The reaction time was fixed at $24 \mathrm{~h}$ except for the effect of reaction time experiments. The saponin concentration was fixed at the optimum condition aside from the effect of different concentrations. The suspensions were shaken continuously in a shaker at $200 \mathrm{rpm}$ at room temperature. At the end of the experiments, the
Table 2 Influencing factors on heavy metal removal with saponin ${ }^{a}$

\begin{tabular}{llll}
\hline $\begin{array}{l}\text { Test A } \\
\text { concentration }\left(\mathrm{g} \mathrm{L}^{-1}\right)\end{array}$ & $\begin{array}{l}\text { Test B contact } \\
\text { time }(\mathrm{h})\end{array}$ & $\begin{array}{l}\text { Test C liquid/ } \\
\text { solid ratio }\end{array}$ & Test D pH \\
\hline 0.0 & 0 & $5 / 1$ & 2.0 \\
2.0 & 12 & $10 / 1$ & 4.0 \\
4.0 & 24 & $15 / 1$ & 6.0 \\
6.0 & 36 & $20 / 1$ & 8.0 \\
8.0 & 48 & $25 / 1$ & - \\
10.0 & 60 & $30 / 1$ & - \\
12.0 & 72 & $35 / 1$ & - \\
- & - & $40 / 1$ & -
\end{tabular}

${ }^{a}$ The undetermined factors were by reference to practical experience (contact time was $24 \mathrm{~h}, \mathrm{~L} / \mathrm{S}$ ratio was $20 / 1$, pH was initial $\mathrm{pH}$ ) during the single-factor condition optimization experiments.

mixtures were centrifuged at $8000 \mathrm{rpm}$ for $15 \mathrm{~min}$ at $4{ }^{\circ} \mathrm{C}$ and filtered through $0.45 \mu \mathrm{m}$ membrane filters before the analysis while the residue were analysed chemical fractions of heavy metals. A series of three consecutive batch washing experiments were conducted, and a fresh saponin solution was added each time. Deionized water was used as a control for the experiment.

\subsection{Analytical methods}

The $\mathrm{pH}$ value of sludge in deionized water was determined by a pHS-3C pH meter (Shanghai, China). The sludge sample was pretreated by a $\mathrm{SH} 230 \mathrm{~N}$ heavy metals digestion instrument (Jinan, China) with a strong acid digestion $\left(\mathrm{HCl}-\mathrm{HClO}_{4}-\mathrm{HNO}_{3}\right)$ mixture at $180-200{ }^{\circ} \mathrm{C}$. After cooling, solutions were filtered into a $50 \mathrm{~mL}$ glass tube and filled to the mark with dilute nitric acid. Heavy metals concentrations were measured using an Optima5300DV inductively-coupled plasma mass spectrometry (PerkinElmer, USA). Fourier transform infrared (FTIR) spectra were scanned in the range of $400-4000 \mathrm{~cm}^{-1}$ in $\mathrm{KBr}$ pellet on Perkin-Elmer spectrum. X-ray diffraction (XRD) patterns of sludge were obtained using Bruker AXS D8 Advance diffractometer using $\mathrm{Cu}$-Ka radiation $(\lambda=0.15406 \mathrm{~nm})$. The surface morphologies of sludge were observed by using a scanning electron microscope (SEM; FEI QUANTA 2000, The Netherlands). The samples were sputter-coated with gold for $60 \mathrm{~s}$ at 15 $\mathrm{mA}$ prior to the SEM observation. Heavy metals removal efficiencies $(R)$ were calculated using the following equation:

$$
R=(C \times V) /(M \times m) \times 100 \%
$$

where $C$ is the concentration of the heavy metals which removal from sludge in the extraction solution $\left(\mathrm{mg} \mathrm{L}^{-1}\right), V$ is the volume of the extraction solution $(\mathrm{mL}), M$ is the mass of the sludge sample $(\mathrm{g})$, and $m$ is the content of the heavy metals in the sludge sample $\left(\mathrm{mg} \mathrm{kg}^{-1}\right)$. All the tests were performed in triplicate to evaluate the reproducibility of the results, and the average result was reported.

\subsection{Competitive binding experiments}

Removal heavy metal ions from hexahydric heavy metals solution was carried out to study potential of the saponin for 
competitive metal remove. This was done by saponin $(0.8 \mathrm{~g})$ with solution (100 mL each) containing the six heavy metals alone system (Cu(II) (100 mg L ${ }^{-1}$ ), Zn(II) (80 mg L $\left.{ }^{-1}\right), \mathrm{Cr}(\mathrm{VI})$ (50 mg L ${ }^{-1}$ ), Pb(II) $\left(20 \mathrm{mg} \mathrm{L}^{-1}\right), \mathrm{Ni}$ (II) $\left(50 \mathrm{mg} \mathrm{L}^{-1}\right)$ and $\mathrm{Mn}$ (II) $\left.\left(100 \mathrm{mg} \mathrm{L}^{-1}\right)\right)$, and the hexahydric system (Cu(II) $\left(100 \mathrm{mg} \mathrm{L}^{-1}\right)+$ $\mathrm{Zn}$ (II) $\left(80 \mathrm{mg} \mathrm{L}^{-1}\right)+\mathrm{Cr}(\mathrm{VI})\left(50 \mathrm{mg} \mathrm{L}^{-1}\right)+\mathrm{Pb}$ (II) $\left(20 \mathrm{mg} \mathrm{L}^{-1}\right)+\mathrm{Ni}$ (II) $\left(50 \mathrm{mg} \mathrm{L}^{-1}\right)+\mathrm{Mn}$ (II) $\left.\left(100 \mathrm{mg} \mathrm{L}^{-1}\right)\right)$ at $25{ }^{\circ} \mathrm{C}$ and natural $\mathrm{pH}$ for $24 \mathrm{~h}$. At the end of the experiments, the mixtures were centrifuged at $8000 \mathrm{rpm}$ for $15 \mathrm{~min}$ at $4{ }^{\circ} \mathrm{C}$ and filtered through 0.45 $\mu \mathrm{m}$ membrane filters and the liquid phase was analyzed for heavy metals using ICP-MS.

\subsection{TCLP test}

The TCLP test followed a procedure depicted in US EPA Method (US EPA, 1995). Analyses were carried out in triplicate. The procedure involves shaking a $1 \mathrm{~g}$ sludge sample in $20 \mathrm{~mL}$ of $0.0643 \mathrm{M} \mathrm{NaOH}$ and $0.0992 \mathrm{M} \mathrm{CH}_{3} \mathrm{COOH}$ extraction solution (1/ 20 ratio) with a $\mathrm{pH}$ of $4.93 \pm 0.05$ for $18 \mathrm{~h}$ on a rotary shaker at about $300 \mathrm{rpm}$. After the reaction, the liquid was separated from solid by filtration through $0.45 \mathrm{um}$ filter and the liquid phase was analyzed for heavy metals using ICP-MS.

\subsection{Sequential extraction experiments}

To clarify the effect of the process on the heavy metals fractions in the dewatered sludge, sequential extraction was performed using the modified BCR (Community Bureau of Reference) method. ${ }^{17}$ The method procedures were described in Table 3. At each extraction step, the mixed suspensions were centrifuged at $8000 \mathrm{~g}$ for $15 \mathrm{~min}$ at $4{ }^{\circ} \mathrm{C}$ and the supernatant samples were then filtered by a cellulose membrane with a pore size of $0.45 \mu \mathrm{m}$ filter. The obtained residual sludge was rinsed by deionized water and the filtrate was collected for the next step. The start of the next step in the extraction process was marked by adding the extraction chemical agent into the residue. At each step nitric acid was added to the filtrate $50 \mathrm{~mL}$ before analysis.

\subsection{Heavy metal stability and mobility in the sludge}

Heavy metal stability was calculated using the $I_{\mathrm{R}}$ index, which shows the relative binding intensity of heavy metals according to the BCR sequential extraction. $I_{\mathrm{R}}$ was defined as follows. ${ }^{32}$

$$
I_{\mathrm{R}}=\left(\sum_{i=1}^{k} i^{2} F_{i}\right) / k^{2}
$$

where $F_{i}$ is the percentage (fractions content) of the heavy metal in the solid-phase component $i$ out of the total extracted, and $i$ is the number of the extraction step, processing from the least aggressive to most aggressive extractant (in our the BCR extraction procedure, $k=4) . I_{\mathrm{R}}$ values range from 0 to 1 . This parameter has been introduced to quantitatively express the relative adhesive strength of heavy metals in dewatered sludge. Therefore, a high value (close to 1 ) indicates a high proportion of the metal is integrated into the residual fraction, which indicated that heavy metals were tightly bonded to the sludge, whereas a low value of $I_{\mathrm{R}}$ (close to 0 ) indicates a distribution pattern in which the metal mainly exists in the soluble and exchangeable fractions (heavy metals were weakly bonded to the sludge). Intermediate values display various patterns of heavy metal partitioning among solid-phase components. ${ }^{32}$

In order to evaluate relative mobility of heavy metals in sludge and bio-available speciation, the $M_{\mathrm{F}}$ parameter was used a ratio of heavy metals content in the mobile fraction to the sum of all fractions. ${ }^{32}$

$$
M_{\mathrm{F}}=F_{1} /\left(F_{1}+F_{2}+F_{3}+F_{4}\right) \times 100 \%
$$

According to the modified BCR procedure, four operationally defined fractions were determined for each heavy metal, exchangeable fraction $\left(F_{1}\right)$, reducible fraction $\left(F_{2}\right)$, oxidizable fraction $\left(F_{3}\right)$, residual fraction $\left(F_{4}\right)$. High $M_{\mathrm{F}}$ values have been elucidated the relatively easy mobility of heavy metals and the biological availability in before and after treatment sludge.

\section{Results and discussion}

\subsection{Optimization conditions of sludge washing}

The removal efficiency of the target heavy metals demonstrated slightly different trends under the four effective factor conditions (as shown in Fig. 2). Concentration, contact time, liquid/ solid ratio and $\mathrm{pH}$ of washing agents had notable influence on removal efficiency.

3.1.1. Concentrations of saponin. The removal efficiencies of heavy metals by different concentrations of saponin under the conditions of liquid/solid ratio of 20/1, washing time of $24 \mathrm{~h}$, and initial pH are shown in Fig. 2(A). Generally, a high saponin washing agent concentration would cause high heavy metals removal efficiency. Mn rather than other heavy metals, seemed less dependent on the saponin washing agent, owing to the dominantly existence of the anionic form of $\mathrm{Mn}$ and $\mathrm{Pb}$ hardly from stable complex with the saponin and Mn mainly existed oxidizable and residual fractions in the sludge. ${ }^{37}$ Saponin was more effective for others heavy metals due to the mechanism of ligand exchange and complexation and acid effect. ${ }^{32,34}$ The

\begin{tabular}{|c|c|c|c|}
\hline Step & Metal fraction & Extraction agents & Extraction conditions \\
\hline$F_{1}$ & Sludge solution, carbonates, exchangeable metals & $\mathrm{CH}_{3} \mathrm{CHOOH}(0.11 \mathrm{M})$ & $16 \mathrm{~h}$, room temperature \\
\hline$F_{2}$ & Iron/manganese oxyhydroxide (reducible) & $\mathrm{NH}_{2} \mathrm{OH} \cdot \mathrm{HCl}(0.1 \mathrm{M}$ at $\mathrm{pH} 2)$ & $16 \mathrm{~h}$, room temperature \\
\hline$F_{3}$ & Organic matter and sulfides (oxidizable) & $\mathrm{H}_{2} \mathrm{O}_{2}(8.8 \mathrm{M})$ then $\mathrm{CH}_{3} \mathrm{COONH}_{4}(1.0 \mathrm{M})$ at pH 2 & $\begin{array}{l}85^{\circ} \mathrm{C}, 2 \mathrm{~h} \text {, then } 16 \mathrm{~h} \text {, } \\
\text { room temperature }\end{array}$ \\
\hline$F_{4}$ & Residual, non-silicate bound metals & $\mathrm{HF}-\mathrm{HClO}_{4}-\mathrm{HNO}_{3}$ & $6 \mathrm{~h}, 190^{\circ} \mathrm{C}$ \\
\hline
\end{tabular}

Table 3 Sequential extraction concentrations of heavy metals for sludge sample 
(A)

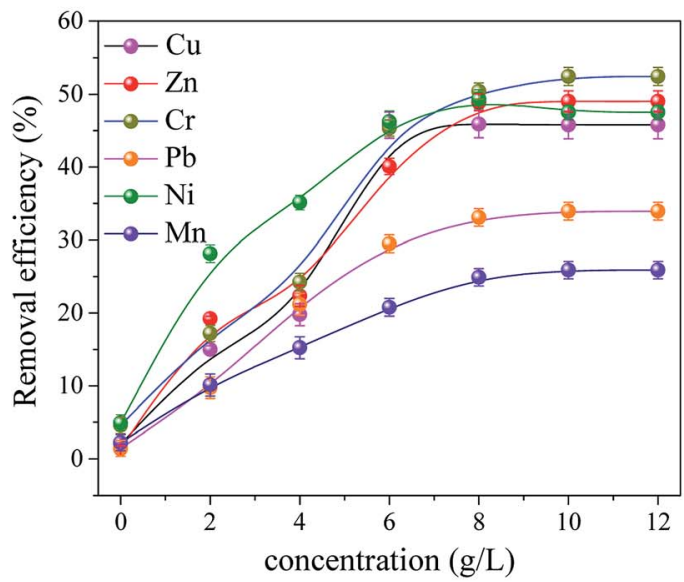

(C)

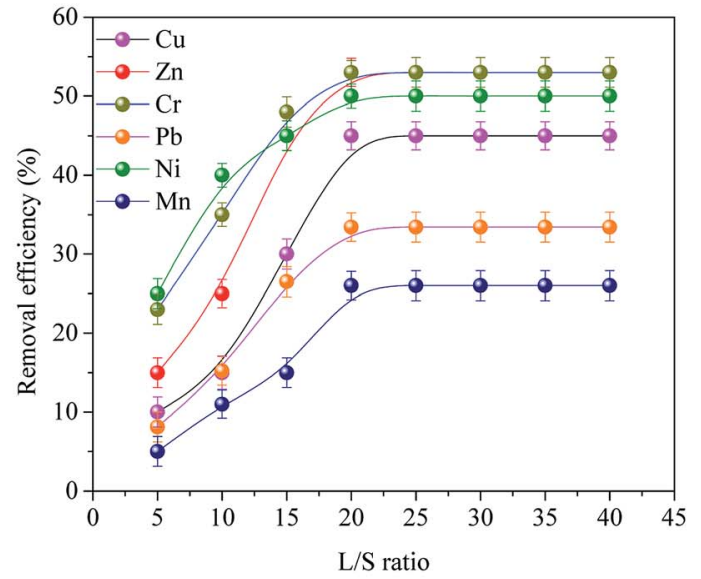

(B)

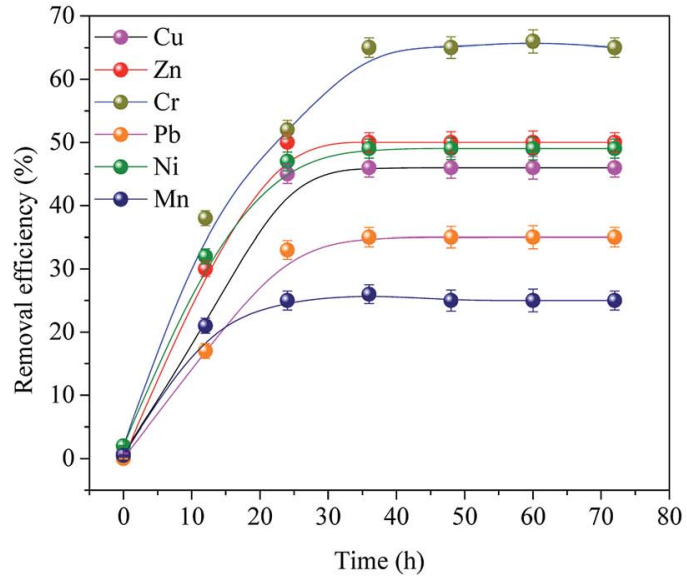

(D)

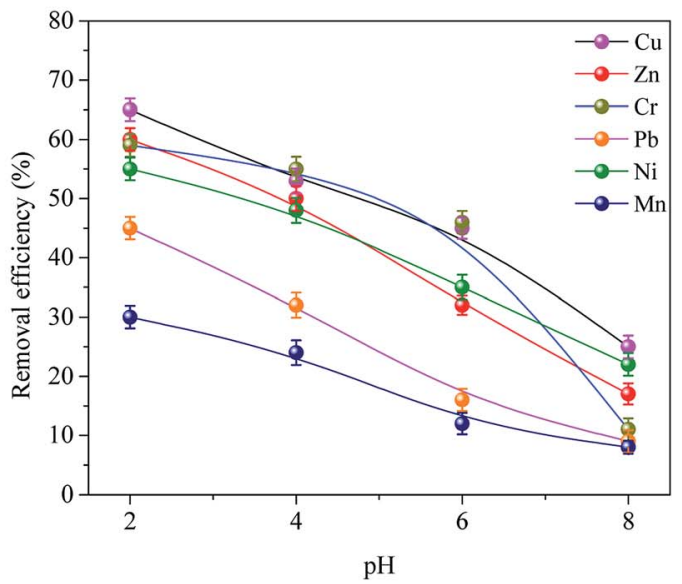

Fig. 2 Extraction efficiencies of heavy metal with different conditions. (A) Concentration, (B) time, (C) L/S ratio and (D) pH.

removal efficiencies for saponin increased sharply with raised in their concentrations up to $0.0 \mathrm{~g} \mathrm{~L}^{-1}$ and $8.0 \mathrm{~g} \mathrm{~L}^{-1}$. When the saponin concentration was more than $8.0 \mathrm{~g} \mathrm{~L}^{-1}$, heavy metals removal efficiencies increased slowly. Higher concentration failed to contribute to enhancement of the heavy metals removing efficiencies. However, the concentration is lower than $8.0 \mathrm{~g} \mathrm{~L}^{-1}$, saponin is effective in removing cationic heavy metals and functional groups of saponin can enhance heavy metals mobility. Heavy metals removal efficiencies increased with saponin concentration increased. Removal efficiencies increased to a maximum value of $24.89-50.42 \%$ before it reached a constant level or fluctuated in a small range. Overall, in order to obtained the best removal efficiencies for heavy metals, $8.0 \mathrm{~g} \mathrm{~L}^{-1}$ of saponin was the best washing agent concentration.

3.1.2. Contact time. Fig. 2(B) indicated that rapid desorption occurred within $0-24 \mathrm{~h}$ for the saponin of washing agent, then heavy metals desorption preserved a relatively stable state. The time-dependent extracting process might be primarily caused by the rate-limited dissolution and desorption of heavy metal and the heavy metal dissolution/desorption may be a more important factor in sludge extraction. Extracted heavy metals were likely to be re-precipitated or re-adsorbed onto the sludge minerals under relatively long contact time. Take into consideration the experimental cost and removal efficiency, contact time of $24 \mathrm{~h}$ was the best choice for the following test.

3.1.3. Liquid/solid ratio. Liquid/solid ratio is a vital parameter in sludge washing and contributes substantially to the overall removal and extraction of contaminants as well as the amount of residual wash water that must be treated. Experiment was performed with concentration saponin at $8.0 \mathrm{~g}$ $\mathrm{L}^{-1}$. As shown in Fig. 2(C), liquid/solid ratio has obvious impact on removal of the target heavy metals. The lower liquid/solid ratio cause insufficient mixing between heavy metal and washing agents which affected the removal efficiency obviously. The removal efficiency of $\mathrm{Cu}, \mathrm{Zn}, \mathrm{Cr}, \mathrm{Pb}, \mathrm{Ni}$ and $\mathrm{Mn}$ at liquid/ solid ratio of $5 / 1$ were $10.00 \%, 15.01 \%, 23.00 \%, 8.09 \%$, $25.00 \%$ and $5.00 \%$, respectively. The heavy metals removal efficiencies generally increased with the raised of the liquid/ solid ratio. The highest removal efficiencies were $45.00 \%$, $53.00 \%, 53.12 \%, 33.41 \%, 50.02 \%$ and $26.12 \%$, respectively, when the liquid/solid ratio increased to $20 / 1$. However, there 
were no notable changes in the removal efficiency for heavy metals at the liquid/solid ratios above 20/1. Overall, 20/1 of saponin was the best washing agent liquid/solid ratio.

3.1.4. pH. Solution $\mathrm{pH}$ is vital important factor determining the extraction efficiency, because it can affect heavy metal retention by the sludge as well as the capability of washing agents to extract the contaminants from sludge through different mechanisms. Fig. 2(D) indicated that the influence of $\mathrm{pH}$ on heavy metals removal efficiencies was different. It demonstrated that fraction of $\mathrm{Pb}$ and $\mathrm{Mn}$ were stabler than other heavy metals in acid and alkaline conditions, due to $\mathrm{Pb}$ and $\mathrm{Mn}$ mainly existed oxidizable and residual fractions in sludge. Fig. 2(D) indicated that heavy metals removal efficiencies generally decreased with the increase of the solution pH. High extraction efficiencies of heavy metals were achieved at $\mathrm{pH} 2.0$ of saponin washing agents. Actually, the solution $\mathrm{pH}$ controlled within the range of 5.0-8.0 in order to avoid the damage of sludge nutrient (nitrogen, phosphorus and organic matter) under too acid or alkaline conditions. The acid environment was conducive to the release of $\mathrm{Fe} / \mathrm{Mn}$ from oxides in sludge via ligand enhanced heavy metals dissolution. ${ }^{37}$ The $\mathrm{pH}$ of $8.0 \mathrm{~g} \mathrm{~L}^{-1}$ saponin was about 5.10. In consideration of heavy metals removal efficiency, the original $\mathrm{pH}$ of saponin was chosen for the sludge washing.

\subsection{Kinetic model of heavy metals extraction}

In order to determine the reaction rate and equilibrium time of the desorption process, the desorption kinetics was studied. Kinetic model of heavy metals extraction efficiencies of great importance for understanding insight on heavy metal release. Heavy metals desorption kinetic experimental results were illustrated in Fig. 2(B).

As shown in Fig. 2(B), the heavy metals extraction by the saponin was a rapid process which required about $24 \mathrm{~h}$ to approach equilibrium at the same temperature. After reaching equilibrium, there was no significant extraction of heavy metal ions, which was due to the fact that the decrease of concentration difference between the massive solution and sludge particle surface reduced the power of mass transfer in the desorption process. Besides, the reaction capacity of saponin on heavy metal ions increased with the raised of reaction temperature.
In order to investigate the kinetic mechanism involved in the desorption process, five kinetic models namely pseudo-first order, pseudo-second order, Elovich, parabolic diffusion and two-constant rate equation model has been adopted to fit the kinetic data. Results showed that heavy metals from the sludge were successfully depicted by the five kinetic models according to the significant $R^{2}$ values demonstrated in Table 4 . As can be observed, the pseudo-second order equation, $R^{2}$ values of heavy metals were more than 0.997 , which demonstrated it be better fitting model than the other four models, which indicated that the rate-determining step of the desorption process was liquidsolid film. Then the heavy metal desorption data was analyzed by the pseudo-second order model, and the model fitting results were shown in the Fig. 3 and Table 4 . The pseudo-second order model equation was:

$$
\frac{t}{q_{t}}=\frac{1}{k_{2} q_{\mathrm{e}}^{2}}+\frac{t}{q_{\mathrm{e}}}
$$

where $q_{\mathrm{e}}$ and $q_{t}$ were the amount of heavy metal ions ( $\mathrm{mg} \mathrm{kg}^{-1}$ ) at equilibrium and at time $t$, respectively; $k_{2}$ was the rate constant of the pseudo-second order model.

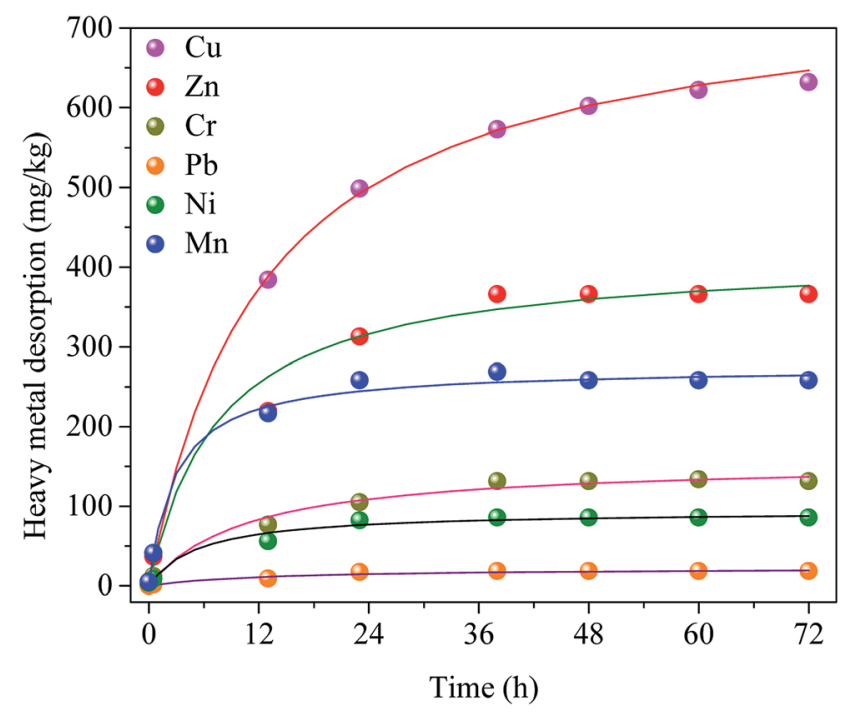

Fig. 3 Pseudo-second order kinetics for heavy metal desorption from the sludge.

Table 4 Coefficients of determination $\left(R^{2}\right)$ and standard errors of estimate (SEE) for the kinetic models used to describe heavy metals desorption from sludge with in the presence of saponin solution

\begin{tabular}{|c|c|c|c|c|c|c|c|c|c|c|}
\hline \multirow[b]{2}{*}{ Metals } & \multicolumn{2}{|c|}{$\begin{array}{l}\text { Pseudo-first-order } \\
\text { model }\end{array}$} & \multicolumn{2}{|c|}{$\begin{array}{l}\text { Pseudo-second- } \\
\text { order model }\end{array}$} & \multicolumn{2}{|c|}{ Elovich } & \multicolumn{2}{|c|}{ Parabolic } & \multicolumn{2}{|c|}{$\begin{array}{l}\text { Two-constant rate } \\
\text { equation }\end{array}$} \\
\hline & $R^{2}$ & SEE & $R^{2}$ & SEE & $R^{2}$ & SEE & $R^{2}$ & SEE & $R^{2}$ & SEE \\
\hline $\mathrm{Cu}$ & 0.934 & 0.561 & 0.999 & 0.134 & 0.945 & 0.452 & 0.836 & 1.531 & 0.896 & 0.678 \\
\hline $\mathrm{Zn}$ & 0.953 & 0.762 & 0.997 & 0.154 & 0.973 & 0.543 & 0.834 & 1.535 & 0.897 & 0.542 \\
\hline $\mathrm{Cr}$ & 0.967 & 0.433 & 0.999 & 0.142 & 0.946 & 0.542 & 0.857 & 1.567 & 0.923 & 0.632 \\
\hline $\mathrm{Mn}$ & 0.987 & 0.542 & 0.997 & 0.143 & 0.956 & 0.674 & 0.872 & 1.534 & 0.943 & 0.578 \\
\hline
\end{tabular}


As shown in Table 5, the theoretical calculating values of desorption capacity $\left(q_{\mathrm{e}}\right.$-model) fitted well with the experimental measuring values $\left(q_{\mathrm{e}}\right.$-exp). As shown in Table 4 the parabolic diffusion equation obtained the lowest $R^{2}$ values, varied between 0.734 and 0.897 , which indicated that the absorption irreversibilities. Due to the chemisorption reactions had a much higher activation energy in desorption direction than absorption, the irreversible heavy metal complexes or coordination of heavy metal on the high-energy edge site. ${ }^{38}$

Fig. 4 indicated the series plots of $t / q_{t}$ as a function of extraction time during the transient region $(0-72 \mathrm{~h})$ at various temperatures $\left(20,25,30\right.$ and $\left.35^{\circ} \mathrm{C}\right)$ for the $\mathrm{Cu}, \mathrm{Zn}, \mathrm{Cr}, \mathrm{Pb}, \mathrm{Ni}$ and Mn extraction processes by using the saponin. The experimental results for the $\mathrm{Cu}, \mathrm{Cr}, \mathrm{Pb}, \mathrm{Ni}$ and $\mathrm{Mn}$ demonstrated a good fit with the pseudo-second order model with a good coefficient of determination $\left(R^{2} \geq 0.9952\right)$ at $25{ }^{\circ} \mathrm{C}$, whereas $R^{2}$ for $\mathrm{Zn}$ ranged form 0.9879 to 0.9987 . There were two mechanisms explained the extraction process: a much slower stage related to external diffusion, strong dissolution and scrubbing which reached maximum extraction efficiency.

\subsection{Heavy metal mobilization in the sludge by use of the saponin}

3.3.1. Removal heavy metals during multiple sludge washings using saponin. At the optimal condition, heavy metals extracted from in the sludge by saponin, heavy metals removal efficiencies calculated as three consecutive washing steps were indicated in Fig. 5. The effectiveness of total heavy metals extraction from dewatered sludge were varied.

With the washing number increased, heavy metals removal efficiencies raised gradually. After the first washing, Cr was dominantly removed from the sludge, the highest extraction efficiency was $52.00 \%$. Due to Cr has existed exchangeable and reducible fractions which were easily to transfer into the solution. These two mobile chemical fractions may explain the high removal efficiency from the sludge. For $\mathrm{Cu}, \mathrm{Zn}, \mathrm{Pb}, \mathrm{Ni}$ and $\mathrm{Mn}$, extraction efficiencies were $46.00 \%, 50.00 \%$, 33.00\%, 49.00\% and $23.00 \%$. Zn and Ni extraction efficiencies have similar trends, which extraction efficiency approached to $50.00 \%$. $\mathrm{Zn}$ and Ni partly existed weak bonding in the sludge which explain the both have similar extraction efficiencies. $\mathrm{Cu}$ mainly existed

Table 5 Kinetics parameters for desorption of heavy metals

Pseudo-second-order model

\begin{tabular}{llcc}
\cline { 2 - 4 } Metal & $k_{2}\left(\mathrm{mg} \mathrm{kg}^{-1} \mathrm{~min}^{-1}\right)$ & $\begin{array}{l}q_{\mathrm{e}}-\mathrm{exp}^{a} \\
\left(\mathrm{mg} \mathrm{kg}^{-1}\right)\end{array}$ & $\begin{array}{l}q_{\mathrm{e}}-\mathrm{model}^{b} \\
\left(\mathrm{mg} \mathrm{kg}^{-1}\right)\end{array}$ \\
\hline $\mathrm{Cu}$ & $1.79 \times 10^{-6}$ & 601.97 & 602.68 \\
$\mathrm{Zn}$ & $5.27 \times 10^{-6}$ & 365.79 & 369.85 \\
$\mathrm{Cr}$ & $9.96 \times 10^{-6}$ & 133.66 & 133.56 \\
$\mathrm{~Pb}$ & $5.63 \times 10^{-5}$ & 18.38 & 18.62 \\
$\mathrm{Ni}$ & $3.24 \times 10^{-5}$ & 85.80 & 86.49 \\
$\mathrm{Mn}$ & $2.14 \times 10^{-5}$ & 258.33 & 259.40
\end{tabular}

${ }^{a}$ The experimental measuring values of desorption capacity. ${ }^{b}$ The theoretical calculating values of desorption capacity. oxidizable and residual fractions in the sludge. Conversely, $\mathrm{Zn}$ mainly existed exchangeable and reducible fractions in the sludge, which explained extraction efficiency of $\mathrm{Zn}$ higher than $\mathrm{Cu}$. For $\mathrm{Pb}$ and $\mathrm{Mn}$, have low extraction efficiency in these heavy metals. Due to $\mathrm{Pb}$ and $\mathrm{Mn}$ mainly existed oxidizable and residual fractions in the sludge, the residual fraction which mainly bound with the organic matter, sulfides and silicate, formed the stable state in the sludge ${ }^{39,40}$ was difficult to extract from sludge under the saponin washing solution. After the second and third washing, the accumulated extraction efficiencies maintained steady growth.

To elucidate the heavy metal ions removal with the aid of saponin, it is essential to take the heavy metal ion-ligand interaction into consideration. The complexation is described by the formation of stable metal to ligand complexes as major species. The chemical reaction between the heavy metal ions and the functional groups of saponin can be described as follows:

$$
\text { Sludge- } \mathrm{M}^{n+}+\mathrm{R}-(\mathrm{COOH})_{m} \rightarrow \text { sludge }+\mathrm{R}-\mathrm{M}^{n+}-(\mathrm{COOH})_{m}
$$

As can be observed from eqn (5), it can help us to understand that saponin enhanced heavy metals extraction from sludge as following: saponin could act as organic ligands, due to the carboxylic functional groups of saponin. Heavy metal ions extraction by saponin was based on the affinity of the saponin ligand for heavy metal ions. The extent of complexation between saponin ligands and heavy metal ions mainly relied on the competition between the metal-binding functional groups from the sludge structure and the saponin for the heavy metal. Heavy metal ions that formed more stable complexes with the saponin than with the sludge particles functional groups. It cloud be deduced that $\mathrm{Cr}$ obtained the highest extraction efficiency might be attributed to its strong complexing tendency with saponin, while $\mathrm{Mn}$ and $\mathrm{Pb}$ seemed to form more stable complexes with the sludge functional groups than with saponin.

The stability constant $(\log K)$ of metal ions chelate with saponin were investigated, and heavy metals chelating ability orders were: $\log K[\mathrm{Cu}(\mathrm{II})](6.60)>\log K[\mathrm{Zn}(\mathrm{II})](4.32)>\log K$ $[\mathrm{Cd}(\mathrm{II})](4.12)>\log K[\mathrm{~Pb}(\mathrm{II})](3.91),{ }^{41}$ these data indicated that saponin has a strong ability to chelate heavy metals, and obtained dominant removal efficiency. As can be observed in Fig. 5, in this work, heavy metals removal efficiencies orders were: $\mathrm{Cr}>\mathrm{Zn}>\mathrm{Cu}>\mathrm{Ni}>\mathrm{Pb}>\mathrm{Mn}$. Because the stability constant showing the ability to form complexes is measured under the aqueous solution without other influencing factor conditions.

Obviously, saponin has a strong capability to chelate $\mathrm{Cu}, \mathrm{Zn}$, $\mathrm{Cr}, \mathrm{Pb}, \mathrm{Ni}$ and $\mathrm{Mn}$. Thus, it is easy to explain saponin can remove heavy metals from sludge quite effectively. However, actual removal efficiency orders were: $\mathrm{Cr}>\mathrm{Zn}>\mathrm{Cu}>\mathrm{Ni}>\mathrm{Pb}>$ $\mathrm{Mn}$, which is not consistent with the trend displayed above. Because the stability constant demonstrating the capability of forming complexes is measured in the deionized water. However, in the real wastewater and sludge, the impact of competitive parameters, especially the environmental $\mathrm{pH}$ values were taken into account, it would result in different extraction 

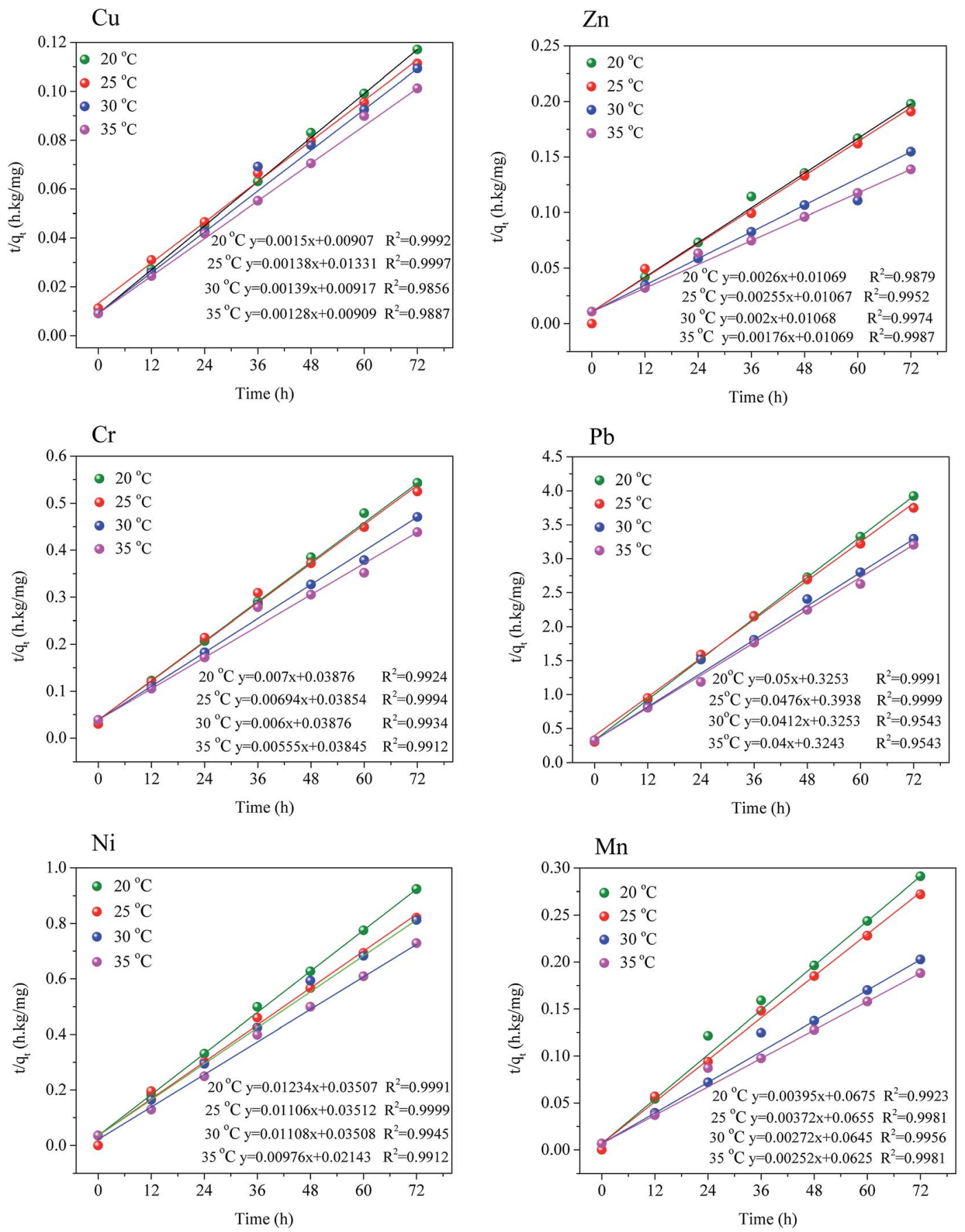

Fig. 4 Pseudo-second order reaction for heavy metal different temperatures.

efficiencies sequences in reality compared to the theoretical one. The $\mathrm{pH}$ values can significantly affect the extraction efficiency and the stability constant in the real and ideal environment.

The comparison of saponin with other techniques in terms of enhanced reagents, reaction time and removal efficiencies for heavy metals were presented in Table 6. Although saponin has lower removal efficiencies for $\mathrm{Zn}$ and $\mathrm{Pb}$ than ultrasoundassisted nitric acid, it has a comparative removal efficiency of $\mathrm{Cu}, \mathrm{Zn}, \mathrm{Cr}, \mathrm{Pb}$ and Ni with other techniques, as well as a much better removal efficiency. The higher removal efficiency may attribute to the saponin dissolve the proteins and carbohydrates of sludge particles, and then the functional groups take effects in the removal process.

3.3.2. Removal heavy metal factions during multiple sludge washings using saponin. An understanding of the extracting behavior of heavy metal is very important for evaluating fractions of heavy metal extraction efficiencies. Varied fractions of heavy metals in the extraction procession were investigated. Heavy metals fractions removal efficiencies were 


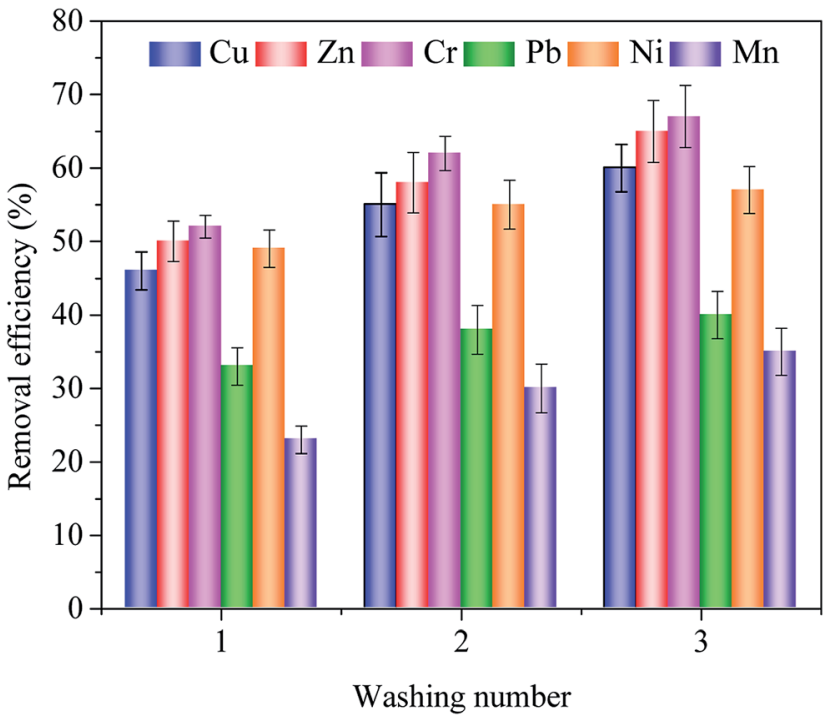

Fig. 5 The influence of three-step washing on the removal efficiencies of heavy metals by the saponin.

indicated in Fig. 6. Generally, the four fractions of heavy metals have a similar extracting trend, fractions removal efficiencies could raise with the washing number increased from 1 to 3 .

After the first extraction, the exchangeable fraction of $\mathrm{Ni}$ obtained the highest extraction efficiency, due to heavy metal ions mainly bound with the carbonates and surface of sludge particle, they formed exchangeable fraction in the sludge, which led to the fraction was easily extracted from the sludge. ${ }^{16,37,42}$ As well as, the saponin have many functional groups such as hydroxyl and carboxyl that formed complex with heavy metals ions. Mn exchangeable fraction also obtained excellent extraction efficiency (56.12\%). Because the Mn exchangeable fraction was weakly bonded, and overall this fraction accounts for $11.23 \%$ of the $\mathrm{Mn}$ in the untreated sludge. $\mathrm{Pb}$ has high stability constant with the saponin, which led to accelerating into the solution. $\mathrm{Cu}, \mathrm{Zn}$, and $\mathrm{Cr}$ exchangeable fractions had lower extraction efficiencies $(35.77 \%, 16.00 \%$, and $12.00 \%$, respectively) than other heavy metals. Due to $\mathrm{Cu}, \mathrm{Zn}$, and $\mathrm{Cr}$ ions have more strong bonding with the sludge particles than saponin. Generally speaking, four heavy metals ( $\mathrm{Ni}, \mathrm{Mn}, \mathrm{Pb}$ and $\mathrm{Cu}$ ) exchangeable fractions removal efficiencies exceeded $35.77 \%$ after the first washing, and two ( $\mathrm{Zn}$ and $\mathrm{Cr}$ ) were lower. After the third washing, heavy metals obtained better extraction efficiencies, which exceeded $56.54 \%$. The exchangeable fraction played important role in heavy metal total content extraction efficiency.

For heavy metal reducible fraction, after the third washing, the reducible fractions of $\mathrm{Zn}, \mathrm{Cr}, \mathrm{Pb}$ and $\mathrm{Ni}$ had better removal efficiencies which exceeding $65.00 \%$. Especially, $\mathrm{Ni}$ had the highest reducible fraction extraction efficiency. Due to the reducible fraction was mainly contained iron and manganese oxyhydroxides which were easily reacted with saponin to enhance $\mathrm{Ni}$ dissolved into the solution. $\mathrm{Pb}$ and $\mathrm{Cr}$ reducible fractions obtained the similar extraction efficiencies which were $65.00 \%$ and $67.44 \%$, respectively. Although $\mathrm{Pb}$ and $\mathrm{Cr}$ found mainly associated with residual and oxidizable fractions in the before washing sludge, exchangeable and reducible fractions extraction efficiencies exceeded $65.00 \%$. Especially, total $\mathrm{Cu}$ and $\mathrm{Mn}$ removal efficiencies was lower, due to it was mainly associated with oxidizable and residual fractions. ${ }^{43}$ The Mn residual fraction was difficult to extract under the saponin condition. For reducible fractions of $\mathrm{Cu}$ and $\mathrm{Mn}$ achieved lower removal efficiencies than other four heavy metals. Due to the reducible fractions associated with iron and manganese oxyhydroxides closely. ${ }^{6}$

The oxidizable fractions of $\mathrm{Cr}$ and $\mathrm{Pb}$ achieved better removal efficiencies, which were $65.64 \%$ and $70.99 \%$. $\mathrm{Pb}$ had the highest removal efficiency, due to the oxidizable fraction was only $15.41 \%$ in all the fractions. $\mathrm{Pb}$ and $\mathrm{Cr}$ oxidizable fractions obtained similar extraction efficiencies. $\mathrm{Cu}$ and $\mathrm{Mn}$ oxidizable fractions achieved lower extraction efficiencies than the other heavy metals, due to $\mathrm{Cu}$ and $\mathrm{Mn}$ was mainly associated with the oxidizable and residual fractions, respectively, in the before washing sludge. Besides, the oxidizable fractions of $\mathrm{Zn}$ obtained the lower removal efficiencies than others, which was $49.66 \%$. Overall, the saponin had better extraction effect about the oxidizable fractions of $\mathrm{Cu}, \mathrm{Zn}, \mathrm{Cr}, \mathrm{Pb}, \mathrm{Ni}$ and $\mathrm{Mn}$. After all, the oxidizable fraction was considered as hard to extract in the dewatered sludge. ,44,45 $^{2,40}$

After the third washing, the residual fraction of $\mathrm{Cu}, \mathrm{Zn}, \mathrm{Cr}$, $\mathrm{Pb}, \mathrm{Ni}$, and $\mathrm{Mn}$ extraction efficiencies were $42.08 \%, 43.13 \%$, $31.28 \%, 8.74 \%, 42.82 \%$, and $35.71 \%$, respectively. The residual fraction of $\mathrm{Zn}$ achieved the best extraction efficiency. Due to $\mathrm{Zn}$

Table 6 Comparison saponin removal efficiencies with other techniques ${ }^{a}$

\begin{tabular}{|c|c|c|c|c|c|c|c|c|c|}
\hline \multirow[b]{2}{*}{ Techniques } & \multirow[b]{2}{*}{ Enhanced reagents } & \multirow{2}{*}{$\begin{array}{l}\text { Reaction } \\
\text { time (h) }\end{array}$} & \multicolumn{6}{|c|}{ Removal efficiencies (\%) } & \multirow[b]{2}{*}{ Reference } \\
\hline & & & $\mathrm{Cu}$ & $\mathrm{Zn}$ & $\mathrm{Cr}$ & $\mathrm{Pb}$ & $\mathrm{Ni}$ & Mn & \\
\hline Electrokinetic remediation & $0.1 \mathrm{~mol} \mathrm{~L}^{-1}$ EDTA & 192 & - & 20 & 34 & 27 & - & - & 17 \\
\hline Electrokinetic remediation & $0.024 \mathrm{~mol} \mathrm{~L}^{-1} \mathrm{SDS}$ & 100 & 31 & 50 & 65 & 26 & 37 & - & 63 \\
\hline Electrokinetic remediation & $0.024 \mathrm{~mol} \mathrm{~L}^{-1}$ citric acid & 100 & 34 & 60 & 69 & 34 & 42 & - & 63 \\
\hline Ultrasound-assisted citric acid & $0.2 \mathrm{~mol} \mathrm{~L}^{-1}$ citric acid & 0.3 & 13.1 & 53.5 & 35.4 & - & 40.2 & - & 4 \\
\hline Ultrasound-assisted nitric acid & $0.352 \mathrm{~mol} \mathrm{~L}^{-1}$ nitric acid & 0.3 & 9.5 & 82.2 & - & 87.3 & - & - & 8 \\
\hline \multirow[t]{2}{*}{ Electrokinetic treatment } & Distilled water & 144 & - & 32.5 & - & - & 47.6 & - & 11 \\
\hline & $8.0 \mathrm{~g} \mathrm{~L}^{-1}$ saponin & 24 & 60 & 65 & 67 & 40 & 57 & 35 & Present study \\
\hline
\end{tabular}

${ }^{a}$ Note: “-”: not mentioned. 

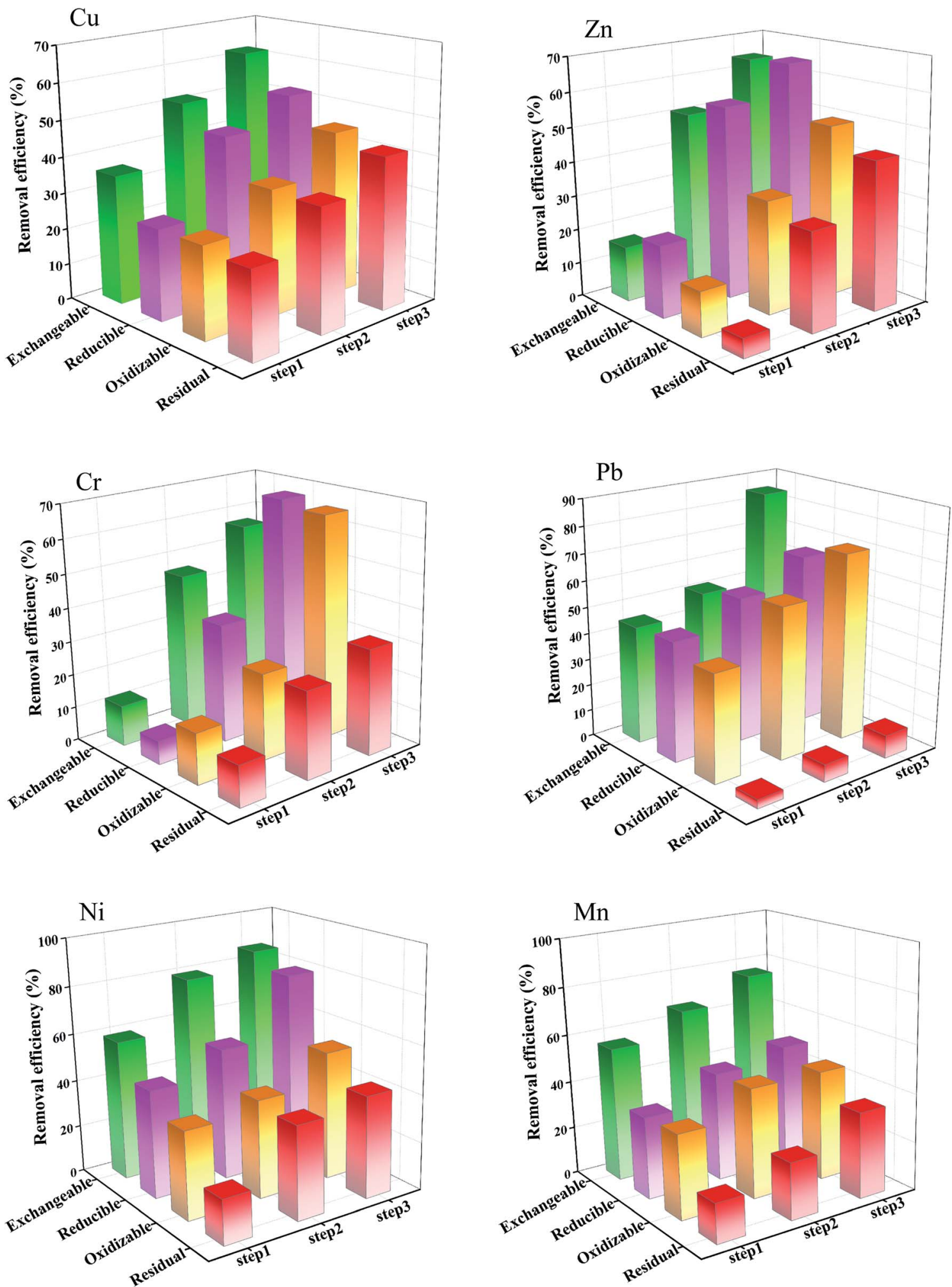

Fig. 6 Fractions removal efficiencies of heavy metal under different sequential washing steps.

has higher affinity with functional groups of saponin than other heavy metals. ${ }^{46-48}$ The residual fractions of $\mathrm{Ni}$ and $\mathrm{Cu}$ obtained better removal efficiencies than $\mathrm{Pb}$ and $\mathrm{Cr}$. Because the $\mathrm{Pb}$ and Cr ions were tightly bounded with the mineral crystal lattice and silicate in the sludge.
After the extraction, heavy metals removal efficiencies increased substantially. In particular, the removal efficiencies for the exchangeable fraction of $\mathrm{Cu}, \mathrm{Zn}, \mathrm{Cr}, \mathrm{Pb}, \mathrm{Ni}$, and $\mathrm{Mn}$ increased. After washing, $\mathrm{Pb}$ and $\mathrm{Ni}$ exchangeable fraction obtained better removal efficiency than others. Due to the $\mathrm{Pb}$ and 
$\mathrm{Ni}$ exchangeable fraction was easily transferred from the dewatered sludge particle into the solution., 16,40,44,49 For the reducible and oxidizable fractions, $\mathrm{Ni}$ and $\mathrm{Pb}$ obtained the better removal efficiencies of $80.55 \%$ and $70.99 \%$, respectively, because these two fractions were easily transferred from the sludge particle into the solution by the saponin treated. For the residual fraction, $\mathrm{Ni}$ obtained the best removal efficiency $(42.83 \%)$. Due to the Ni has a better reaction with saponin. As well as, the saponin reduced the surface tension between the liquid and solid, and had a better solubilization.

3.3.3. Competitive binding of heavy metal ions by saponin. Competitive binding of heavy metal ions by saponin from different hexahydric mixtures was investigated to simulate systems containing multiple heavy metal ions, such as waste water. $^{26,32,50}$ Hexahydric mixtures investigated was $\mathrm{Cu}(\mathrm{II})+\mathrm{Zn}$ (II) $+\mathrm{Cr}(\mathrm{VI})+\mathrm{Pb}(\mathrm{II})+\mathrm{Ni}(\mathrm{II})+\mathrm{Mn}(\mathrm{II})$ and results are demonstrated in Table 7. As can be observed, the removal efficiency of a heavy metal ion in the hexahydric system was less than its value in the single metal ion solution. This is due to the fact that heavy metal ion has no competition between different heavy metal ions for binding site on the surface of saponin in the single heavy metal ion system. As can be seen in Table 7, Cu(II), Zn(II), $\mathrm{Cr}(\mathrm{VI})$ and $\mathrm{Ni}(\mathrm{II})$ have higher removal efficiencies (63\%, 62\%, $60 \%$, and $61 \%$ ) over their competing ions $\mathrm{Pb}$ (II) and $\mathrm{Mn}$ (II) (45\% and $38 \%$ ) in their above mentioned hexahydric systems, respectively, which due to greater stability constant $(\log K)$ and ion exchange capability of $\mathrm{Cu}(\mathrm{II}), \mathrm{Zn}$ (II), $\mathrm{Cr}(\mathrm{VI})$ and $\mathrm{Ni}(\mathrm{II})$ over their competing ions $\mathrm{Pb}(\mathrm{II})$ and $\mathrm{Mn}$ (II), in the hexahydric mixtures, respectively.

\subsection{Influence of saponin washing on heavy metal binding intensity and mobility in sludge}

The effective extraction of the sludge should not be based only on reduction in total heavy metal concentration to meet the agricultural utilization standards for reuse, but also pay close attention to extraction the presence of the removable heavy metals fractions which led to the environmental damage to human health.
$I_{\mathrm{R}}$ and $M_{\mathrm{F}}$ parameters were applied to assess metal binding intensity and mobility. Nowadays, the $I_{\mathrm{R}}$ parameter has been used only to clarified heavy metal binding depending on soil, contamination time and heavy metal loading. ${ }^{32,51}$ In this study, it was applied to assessment heavy metal binding intensity in sludge during the three step washing.

The values of $I_{\mathrm{R}}$ and $M_{\mathrm{F}}$ were measured for heavy metal in sludge before and after saponin washing. $I_{\mathrm{R}}$ and $M_{\mathrm{F}}$ results indicated in Fig. 7 and 8. From the experimental data it followed that heavy metals characterized by various binding intensity defined as $I_{\mathrm{R}}$.

As shown in Fig. 7, the greatest differences in binding intensity were for heavy metals in the sludge. In the before washing sludge, $\mathrm{Cu}, \mathrm{Pb}$ and $\mathrm{Mn}$, the $I_{\mathrm{R}}$ values were $0.25,0.27$ and 0.25 , respectively, which $I_{\mathrm{R}}$ values more than 0.25 , the result showed that $\mathrm{Cu}, \mathrm{Pb}$ and $\mathrm{Mn}$ mainly existed oxidizable and residual fractions in the sludge, demonstrating the strongest bonding of $\mathrm{Cu}, \mathrm{Pb}$ and $\mathrm{Mn}$ to the organic matter, sulfides and silicate. Conversely, the $\mathrm{Zn}, \mathrm{Cr}$ and $\mathrm{Ni}$ have low $I_{\mathrm{R}}$ values were $0.13,0.20$ and 0.18 , respectively. $\mathrm{Zn}, \mathrm{Cr}$ and $\mathrm{Ni}$ were associated with exchangeable and reducible fractions in the sludge, demonstrating that the heavy metals binding intensity was not high.

After three step washing with saponin, apparently influenced heavy metals binding intensity values in the sludge, especially the $\mathrm{Pb}, \mathrm{Ni}$ and $\mathrm{Mn}$, for the $I_{\mathrm{R}}$ values were apparently raised after each washing by the saponin solution. Mn obtained the highest $I_{\mathrm{R}}$ values, both the $\mathrm{Pb}$ and $\mathrm{Ni} I_{\mathrm{R}}$ values also have greatly variation. Conversely, $\mathrm{Zn} I_{\mathrm{R}}$ value varied in a small range from 0.13 to 0.39 , demonstrating that obvious extraction of $\mathrm{Zn}$ from the weak (exchangeable and reducible) fractions, the stable (oxidizable and residual) fractions were still difficult to remove, whereas, the exchangeable and reducible fractions was partly extracted by saponin, which led to $I_{\mathrm{R}}$ value lower than others.

However, the $I_{\mathrm{R}}$ value was closely associated with the $M_{\mathrm{F}}$. Generally, the higher the relative binding intensity $\left(I_{\mathrm{R}}\right)$ indicated that the low the heavy metals mobility. Fig. 8 indicated heavy metals mobility before and after washing by the saponin. Despite the smallest variation in $I_{\mathrm{R}}$ for $\mathrm{Zn}$ in the sludge, the $M_{\mathrm{F}}$

Table 7 Heavy metal removal efficiencies for single heavy metal system and hexahydric system by saponin

Heavy metal

ion

System

Removal efficiency (\%)

$\mathrm{Cu}(\mathrm{II})$

Zn(II)

$\operatorname{Cr}(\mathrm{vI})$

$\mathrm{Pb}$ (II)

Ni(II)

$\mathrm{Mn}$ (II)

$\mathrm{Cu}$ (II)

Zn(II)

$\mathrm{Cr}(\mathrm{vI})$

$\mathrm{Pb}$ (II)

$\mathrm{Ni}($ II)

Mn(II)

$\begin{array}{lr}\mathrm{Cu}(\mathrm{II}) \text { alone } & 93 \\ \mathrm{Zn}(\mathrm{II}) \text { alone } & 89 \\ \mathrm{Cr}(\mathrm{VI}) \text { alone } & 89 \\ \mathrm{~Pb}(\mathrm{II}) \text { alone } & 85 \\ \mathrm{Ni}(\mathrm{II}) \text { alone } & 80 \\ \mathrm{Mn}(\mathrm{II}) \text { alone } & 79 \\ \mathrm{Cu}(\mathrm{II})+\mathrm{Zn}(\mathrm{II})+\mathrm{Cr}(\mathrm{VI})+\mathrm{Pb}(\mathrm{II})+\mathrm{Ni}(\mathrm{II})+\mathrm{Mn} \text { (II) } & 63 \\ \mathrm{Cu}(\mathrm{II})+\mathrm{Zn}(\mathrm{II})+\mathrm{Cr}(\mathrm{VI})+\mathrm{Pb}(\mathrm{II})+\mathrm{Ni}(\mathrm{II})+\mathrm{Mn} \text { (II) } & 62 \\ \mathrm{Cu}(\mathrm{II})+\mathrm{Zn}(\mathrm{II})+\mathrm{Cr}(\mathrm{VI})+\mathrm{Pb}(\mathrm{II})+\mathrm{Ni}(\mathrm{II})+\mathrm{Mn}(\mathrm{II}) & 65 \\ \mathrm{Cu}(\mathrm{II})+\mathrm{Zn}(\mathrm{II})+\mathrm{Cr}(\mathrm{VI})+\mathrm{Pb}(\mathrm{II})+\mathrm{Ni}(\mathrm{II})+\mathrm{Mn} \text { (II) } & 61 \\ \mathrm{Cu}(\mathrm{II})+\mathrm{Zn}(\mathrm{II})+\mathrm{Cr}(\mathrm{VI})+\mathrm{Pb}(\mathrm{II})+\mathrm{Ni}(\mathrm{II})+\mathrm{Mn}(\mathrm{II}) & 38 \\ \mathrm{Cu}(\mathrm{II})+\mathrm{Zn}(\mathrm{II})+\mathrm{Cr}(\mathrm{VI})+\mathrm{Pb}(\mathrm{II})+\mathrm{Ni}(\mathrm{II})+\mathrm{Mn} \text { (II) } & \end{array}$



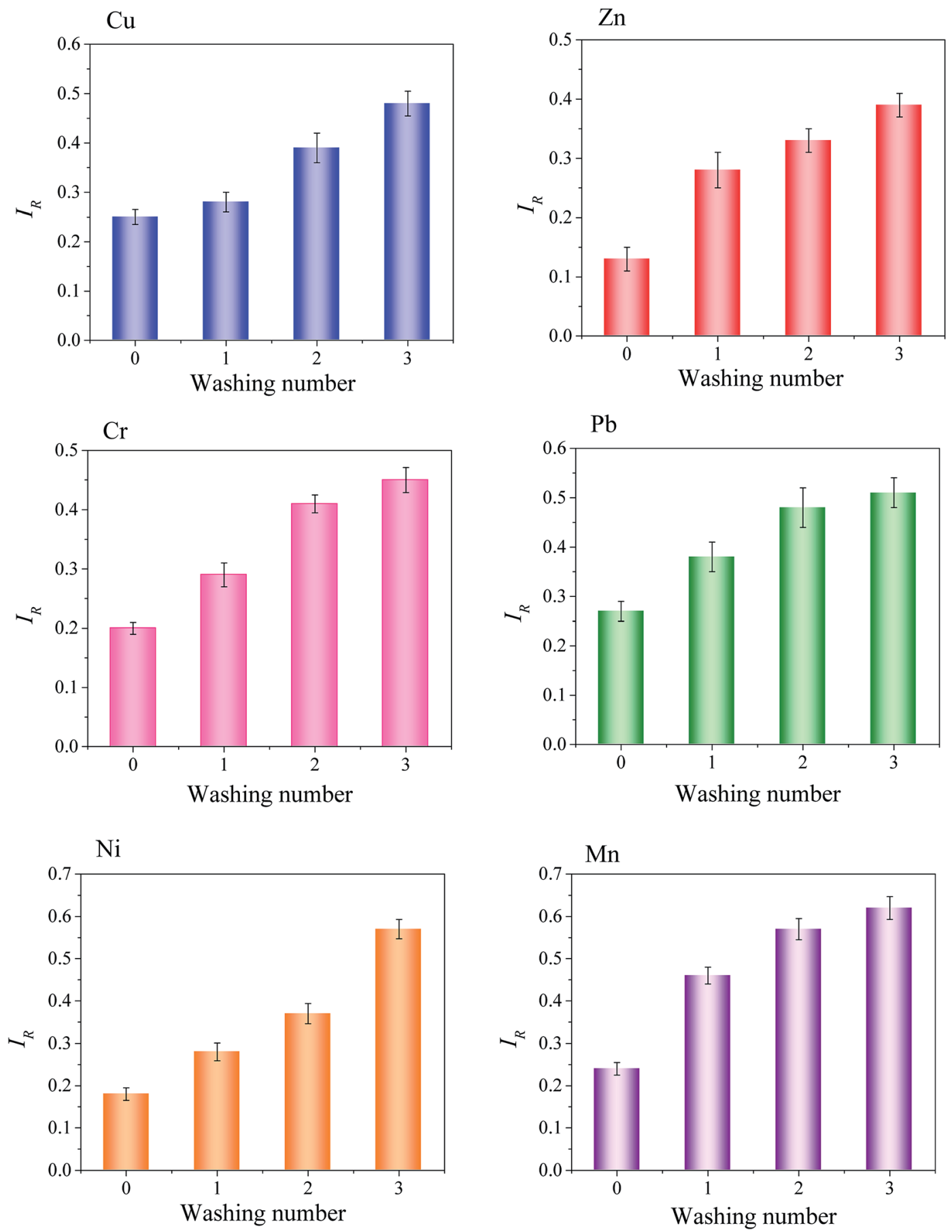

Fig. 7 The changes in the reduced partition index $\left(I_{R}\right)$ for heavy metal in sludge depending on washing number.

was clearly explained the $\mathrm{Zn}$ weak fractions (exchangeable fraction) variation. Therefore, the $M_{\mathrm{F}}$ value was more obvious than $I_{\mathrm{R}}$ value to explain the weak fractions variation during the washing period by saponin. In the sludge, the $M_{\mathrm{F}}$ values showed heavy metals mobility in the before and after washing sludge in Fig. 8. Heavy metals mobility order $\mathrm{Zn}>\mathrm{Ni}>\mathrm{Cu}>\mathrm{Mn}>\mathrm{Cr}>\mathrm{Pb}$ in the sludge. Especially, highest $M_{\mathrm{F}}(25.04 \%)$ for $\mathrm{Zn}$ in the sludge. Due to $\mathrm{Zn}$ was mainly associate with exchangeable and reducible fractions. The lowest $M_{\mathrm{F}}(8.22 \%)$ for $\mathrm{Pb}$ in the sludge.
Due to $\mathrm{Pb}$ was mainly existed in oxidizable and residual fractions.

After extraction, the achieved $M_{\mathrm{F}}$ values proofed the beneficial effect of multiple washing on decreasing heavy metals mobility, which indicated the immobile fractions such as oxidizable and residual fractions were mainly existed in the sludge. After triplicate washing, the $\mathrm{Cu}, \mathrm{Pb}$ and $\mathrm{Mn} M_{\mathrm{F}}$ values were $1.00 \%, 2.05 \%$ and $2.11 \%$ respectively. The result indicated that the less concentration of heavy metal enter into the plants or food chain and less mobility in the sludge. 

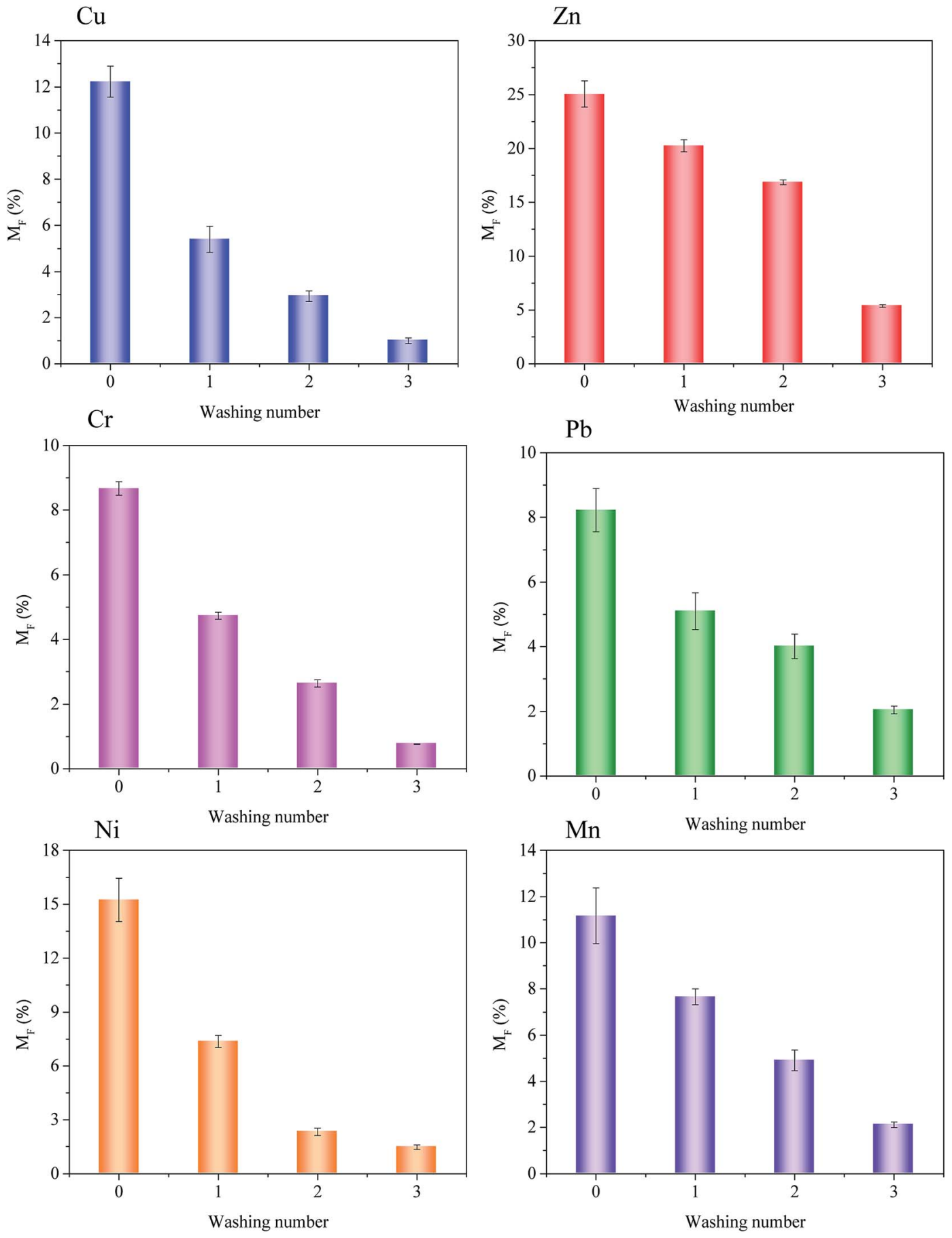

Fig. 8 The changes in the $M_{F}$ for heavy metal in sludge depending on washing number.

\subsection{Leaching behavior (TCLP)}

Table 8 indicated the TCLP concentration of heavy metals before and after washing by saponin. In comparing results at different heavy metal, it was found that the highest TCLP concentration of $\mathrm{Zn}$ before washing. Due to $\mathrm{Zn}$ mainly existed exchangeable and reducible fractions in the sludge, the exchangeable fraction dissolved in the solution. ${ }^{6}$ Meanwhile, Cu TCLP concentration was more than $4.00 \mathrm{mg} \mathrm{L}^{-1}$, due to the exchangeable fraction dissolved in the solution. Conversely, $\mathrm{Pb}$ obtained the lowest TCLP concentration, due to $\mathrm{Pb}$ mainly existed oxidizable and residual fractions, which was difficult to extract from the sludge. After washing, the $\mathrm{Cu}$ and $\mathrm{Zn}$ have higher concentration than other heavy metals, due to exchangeable and reducible fractions dissolved in the solution, however, the $\mathrm{Pb}$ have not detected, due to $\mathrm{Pb}$ mainly existed oxidizable and residual fractions, which was difficult to extract from the sludge. $\mathrm{Cr}$, Ni and Mn TCLP concentration lower than $0.66 \mathrm{mg} \mathrm{L}^{-1}$. The results indicated that more stable heavy metals than before washing by saponin. 
Table 8 Heavy metals concentration in TCLP leachate from the sludge before and after saponin washing ${ }^{a}$

\begin{tabular}{lll}
\hline Metals (unit) & Before value & After value \\
\hline $\mathrm{Cu}\left(\mathrm{mg} \mathrm{L}^{-1}\right)$ & $4.17 \pm 0.93$ & $1.12 \pm 0.11$ \\
$\mathrm{Zn}\left(\mathrm{mg} \mathrm{L}^{-1}\right)$ & $4.86 \pm 0.81$ & $1.06 \pm 0.10$ \\
$\mathrm{Cr}\left(\mathrm{mg} \mathrm{L}^{-1}\right)$ & $0.60 \pm 0.01$ & $0.11 \pm 0.00$ \\
$\mathrm{~Pb}\left(\mathrm{mg} \mathrm{L}^{-1}\right)$ & $0.16 \pm 0.00$ & $\mathrm{LOQ}$ \\
$\mathrm{Ni}\left(\mathrm{mg} \mathrm{L}^{-1}\right)$ & $1.08 \pm 0.03$ & $0.45 \pm 0.01$ \\
$\mathrm{Mn}\left(\mathrm{mg} \mathrm{L}^{-1}\right)$ & $3.77 \pm 0.81$ & $0.66 \pm 0.01$ \\
${ }^{a} \mathrm{LOQ}=$ below limit of quantification. &
\end{tabular}

\subsection{SEM, FITR and XRD analysis}

3.6.1. Morphology analysis. The pretreatments could modify the surface characteristics either by dissolved the protein and lipid or destroying the structure of sludge or by permeating into the sludge. Before washing by saponin, the surface of the sludge was bulk particles, this can be caused by the protein and lipid which have rigid structures, and after washing by the saponin, the structure became more rough and some wrinkles emerged, produced small particles, have a highly porous structure with varying various shapes and dimensions (Fig. 9), due to the saponin enhanced dissolution the particles of the sludge surface, which give rise to the change of sludge particle surface properties, these wrinkles, caves and small particles increased the specific surface area, which contribute to extract much more heavy metals from the sludge, leading to the improvement of extraction efficiency.

3.6.2. FTIR of before and after washing sludge. The FTIR spectra of before and after washing sludge were presented in Fig. 10. The broad absorption in the region of 2924 and 3700 $\mathrm{cm}^{-1}$, with peak centered at $3400 \mathrm{~cm}^{-1}$, can be assigned to the overlapping of $\mathrm{O}-\mathrm{H}$ stretching of water and $\mathrm{N}-\mathrm{N}$ stretching of protein group. The peak at $2147 \mathrm{~cm}^{-1}$ is attributed to M-S$\mathrm{C} \equiv \mathrm{N}$ stretching. The band lying at $1636 \mathrm{~cm}^{-1}$ is attributed to the characteristic amide group, $\mathrm{CO} \cdot \mathrm{NH}$ of proteins, $\mathrm{N}-\mathrm{H}$ bending vibration..$^{52,53}$ Another peak at $1408 \mathrm{~cm}^{-1}$ could be attributed to stretching vibration of $\mathrm{C}=\mathrm{O}$ group in carboxylates. The absorption peaks ranging from 1050 to $1200 \mathrm{~cm}^{-1}$ may corresponded to $\mathrm{C}-\mathrm{O}-\mathrm{O}$ and $\mathrm{C}-\mathrm{O}$, which may be caused by carbohydrates. ${ }^{54-57}$ After washing sludge, the peak at $3414 \mathrm{~cm}^{-1}$ could be attributed to $\mathrm{R}-\mathrm{OH}$ of protein, due to the heavy metal ions reacted with saponin, then transferred into the solution. As well as, after washing the sludge, the peak at $2147 \mathrm{~cm}^{-1}$ has disappeared, due to the saponin reacted the group. The peak at $1348 \mathrm{~cm}^{-1}$ is attributed to stretching vibration of $\mathrm{C}=\mathrm{O}$ group in carboxylates, ${ }^{56}$ which due to the heavy metal ions reacted with the saponin, then the $\mathrm{C}=\mathrm{O}$ group presented in the after washing sludge. Therefore, a conclusion can be concluded that the saponin reacted with heavy metal ions through dissolved the proteins and carbohydrates on the surface of sludge, and promoted the heavy metal ions transferring into the solution.

3.6.3. XRD analysis of the sludge before and after washing. Fig. 11 shows the similarities in the mineral composition of before and after washing sludge. Both samples show the bump of non-crystalline phases at $2 \theta=23-27^{\circ}$ region, ${ }^{58}$ which indicates a siliceous glass structure. The signals consistent with the crystalline phase that are existed in the sludge samples can also be seen in these diffractograms, and quartz is identified as the main crystalline phase. The identification of phases in the obtained XRD patterns could master the formation and transformation of different crystalline phases during the extracting process. The sharp peaks showed the presence of silicon oxide $\left(\mathrm{SiO}_{2}\right)$ and sodium aluminum silicate $\left(\mathrm{NaAlSi}_{3} \mathrm{O}_{8}\right)$ crystals in the sludge before and after extracted by the saponin. The silicon oxide $\left(\mathrm{SiO}_{2}\right)$ content decreased from $71.55 \%$ to $58.19 \%$, due to the saponin extract the protein and carbohydrate, then the part silicon oxide dissolved.

\subsection{Mechanism of saponin enhance extraction heavy metal from the sludge}

According to the above mentioned results, the saponin enhanced heavy metal extraction capacity may be attributed to the introduction of more functional groups, such as carboxyl, hydroxyl in the saponin, and the main mechanism of heavy metals removal was ion exchange and complexation. Fig. 12 schematically elucidated a preliminary four-step mechanism that attribute to the batch washing of acidic heavy metal ions adsorbed on the sludge particles surface by saponin micelles in an aqueous medium.
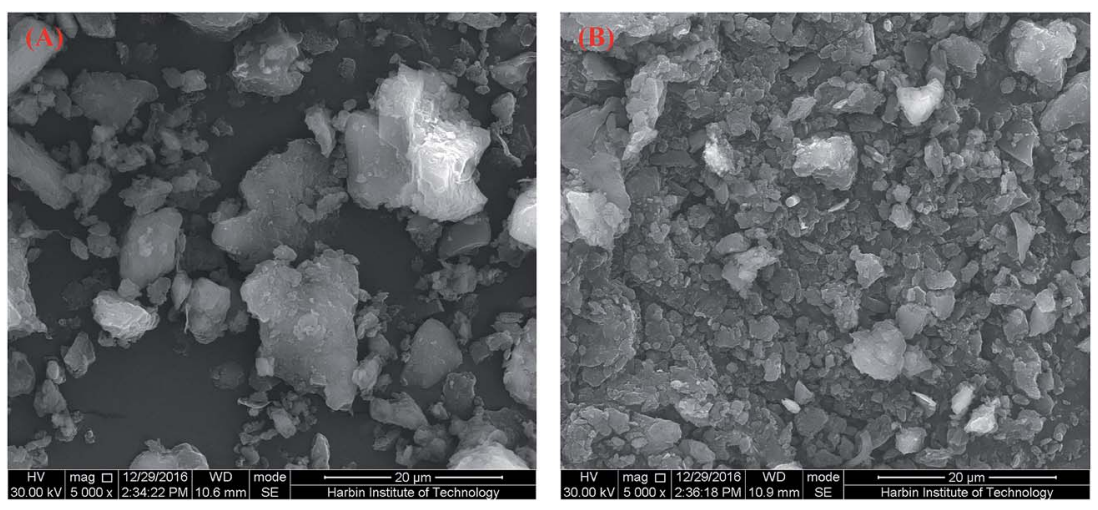

Fig. 9 (A) SEM image of before washing. (B) SEM image of after washing. 


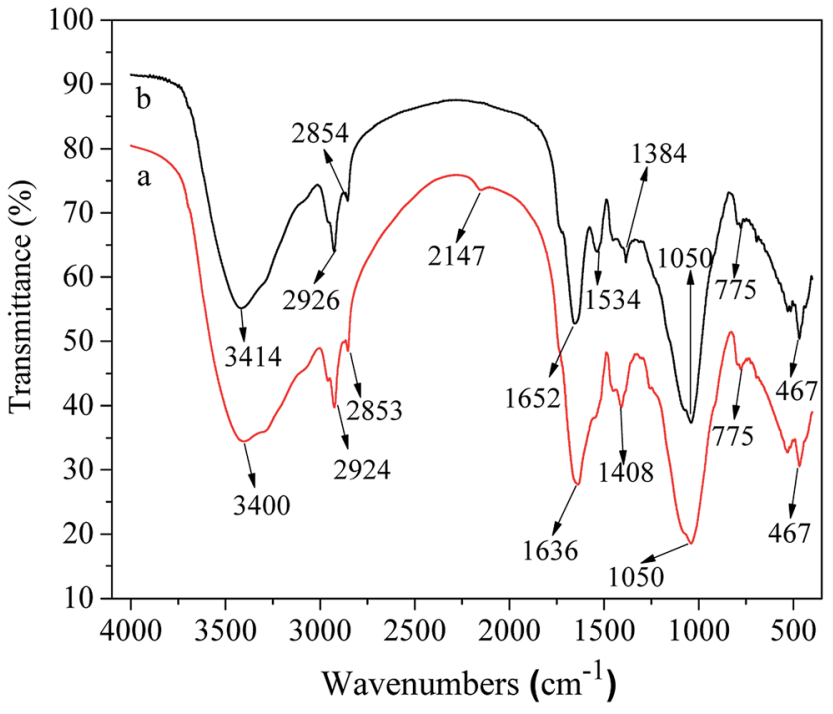

Fig. 10 The FT-IR spectrum of sludge before (a) and after (b) extraction.

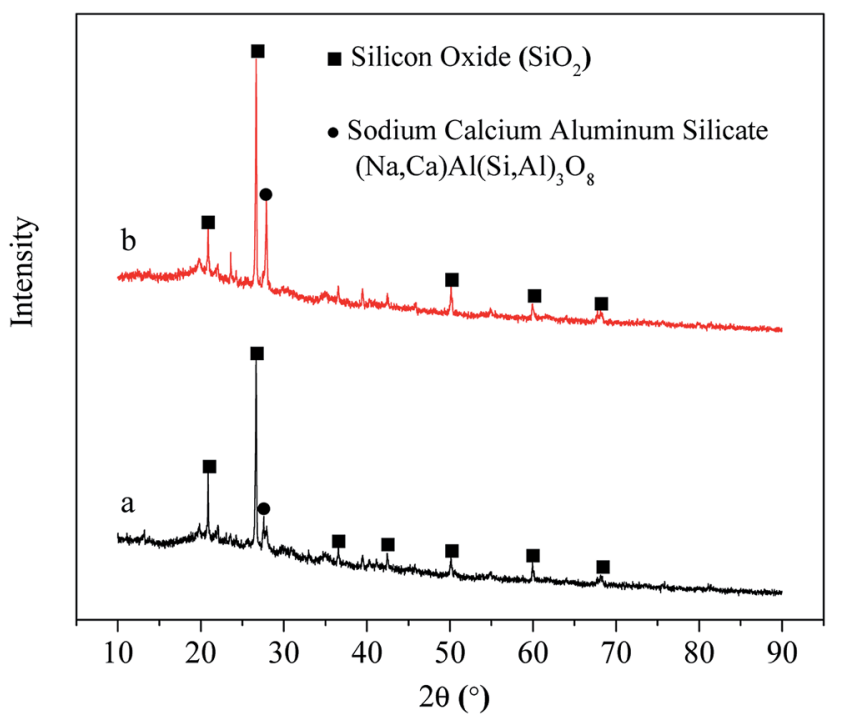

Fig. 11 XRD patterns of the dewatered sludge before and after extraction.

In the first step of washing process with use of saponin concentrations above the CMC value, saponin molecules form a dissociating micelle may readily adsorb at a liquid-solid interface for a period of time and the essence of a reversible dynamic equilibrium, desorb and reorient back into a micelle. ${ }^{27,35}$ In the first step process, which allows Lewis acidbase interactions and electrostatic charge attraction to happen either between acidic cationic metal-spiked surface sites of sludge particles and the saponin hydrophilic anions, or between nonionic hydrophilic polar groups of saponin molecules and the nonmetal-spiked surfaces until a monolayer of surfactant coverage is reached as the first step in the washing process. $^{27,35}$

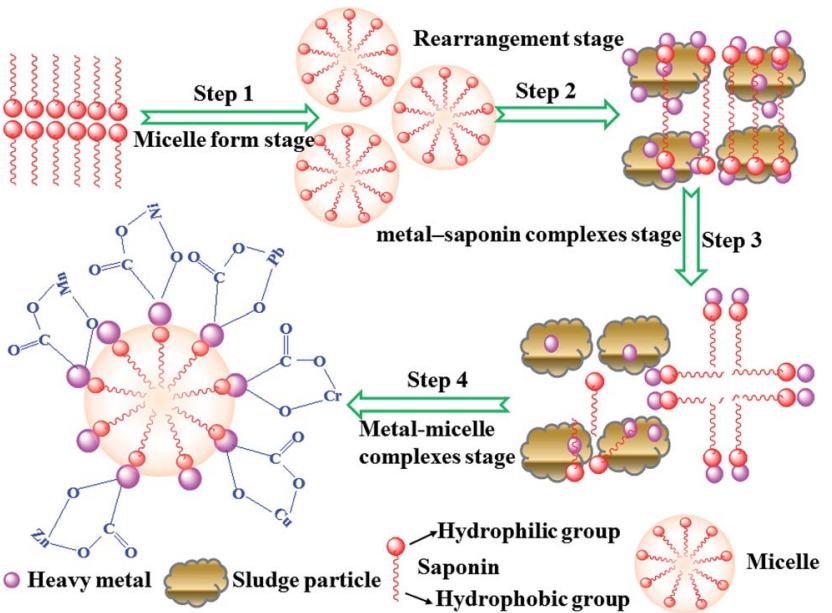

Fig. 12 Mechanism of saponin enhance heavy metal removal from sludge.

The second step involves the continual sorption competition between the adsorbing saponin molecules and the adsorbed metals ions towards the basic surface sites of the sludge particles, which led to the saponin micelles rearrangement, and more adsorption of saponin molecules formed the tail-to-tail and head-to-head state, the breakdown of heavy metal ions pairs buried in the bottom layer, which caused by the spreading film pressure or induced by the high gradient of the tension on an expanding, adsorbed saponin film on sludge surface, ${ }^{32,34}$ in this step the $\mathrm{H}^{+}$transferred into the solution, diffused and exchanged the heavy metal ions on the surface of sludge particles, then the heavy metal ions reacted with the carboxyl, hydroxyl groups. With the contact time increased, the saponin dissolved the protein, lipid and carbohydrates of sludge particles, as well as, the interior heavy metal ions of sludge particles transferred into the solution with the sludge particles destroyed.

In the third step, the orientational rearrangements of the saponin films at the liquid-solid interface, leading to selfassembly of metal-surfactant complexes by aggregation of cage-like hemimicelle on the top of monolayer. ${ }^{27,35,59}$ Heavy metal ions near the saponin hydrophilic anions by ion-pairing attraction at sludge surface would reduce the electrostatic repulsion of head-to-head carboxyl groups of saponin film on the sludge, which augment the curvature of the hemimicelle structure and reduce the effective head area, hence favoring the self-assembly of cage-like saponin-metal micelles at outer layer towards the solution..$^{27,35,60}$

In the last step, a large number of metal-saponin complexes aggregated in the solution, result in metal-micelles formation, due to the enhanced electrostatic screening of other neighboring, exchangeable cations within an electrical double layer. $^{27,35,61}$ The metal-micelle complexes aggregated from the sludge particle proceeds, which carried the heavy metal ions into the solution. Due to a negatively charged saponin film on the sludge particles, surface diffusion and electrostatic repulsion. ${ }^{27,35,61,62}$ 


\section{Conclusions}

This work has shown that saponin provided an effective approach to enhance heavy metals extraction from sludge, and the results indicated that the saponin obtained remarkable extraction efficiency.

(1) The extraction efficiencies generally increased with the raised of influencing factors (except $\mathrm{pH}$ ) within certain limits. The optimal washing conditions were identified as: concentration of $8.0 \mathrm{~g} \mathrm{~L}^{-1}$, contact time of $24 \mathrm{~h}$, liquid/solid ratio of 20/1 and original $\mathrm{pH}$ of washing agent.

(2) The kinetic data were best fitted with the pseudo-second order model $\left(R^{2}>0.997\right)$ for all selected heavy metals.

(3) After washing, $\mathrm{Pb}$ and Ni exchangeable fraction obtained better removal efficiency than others, heavy metals mobility order $\mathrm{Zn}>\mathrm{Ni}>\mathrm{Cu}>\mathrm{Mn}>\mathrm{Cr}>\mathrm{Pb}$ in the sludge.

(4) After washing, TCLP test indicated that $\mathrm{Cu}$ and $\mathrm{Zn}$ have higher concentration than other heavy metals, due to exchangeable and reducible fractions dissolved in the solution. However, the $\mathrm{Pb}$ have not detected in the solution after washing by saponin, due to $\mathrm{Pb}$ mainly existed oxidizable and residual fractions, which was difficult to extract from the sludge.

(5) Saponin enhance heavy metals extraction from the sludge, which main mechanism were complexation, metalbridging and solubilization effect.

\section{Acknowledgements}

This research was financially supported by National Science and Technology Major Project-China (No. 2014ZX07202-011-004), National Key R\&D Program (No. 2016YFE0123400).

\section{References}

1 J. Liang, S. Huang, Y. Dai, L. Li and S. Sun, Water Res., 2015, 84, 243-254.

2 X. Yuan, L. Leng, H. Huang, X. Chen, H. Wang, Z. Xiao, Y. Zhai, H. Chen and G. Zeng, Chemosphere, 2015, 120, 645-652.

3 B. Ebbers, L. M. Ottosen and P. E. Jensen, Chemosphere, 2015, 125, 122-129.

4 X. Wang, J. Chen, X. Yan, X. Wang, J. Zhang, J. Huang and J. Zhao, J. Ind. Eng. Chem., 2015, 27, 368-372.

5 B. Dong, X. Liu, L. Dai and X. Dai, Bioresour. Technol., 2013, 131, 152-158.

6 Q. Wu, Y. Cui, Q. Li and J. Sun, J. Hazard. Mater., 2015, 283, 748-754.

7 G. Peng, G. Tian, J. Liu, Q. Bao and L. Zang, Desalination, 2011, 271, 100-104.

8 J. Deng, X. Feng and X. Qiu, Chem. Eng. J., 2009, 152, 177182.

9 N. M. Zhu, M. Chen, X. J. Guo, G. Q. Hu and D. Yu, J. Hazard. Mater., 2015, 286, 118-126.

10 J. Gao, Q. Luo, C. Zhang, B. Li and L. Meng, Chem. Eng. J., 2013, 234, 1-8.

11 J. Gao, Q. S. Luo, J. Zhu, C. B. Zhang and B. Z. Li, Chemosphere, 2013, 93, 2869-2876.
12 W. Shi, C. Liu, D. Ding, Z. Lei, Y. Yang, C. Feng and Z. Zhang, Bioresour. Technol., 2013, 137, 18-24.

13 F. Song, L. Gu, N. Zhu and H. Yuan, Chemosphere, 2013, 92, 344-350.

14 M. A. A. Zaini, M. Zakaria, N. Alias, Z. Y. Zakaria, A. Johari, S. H. M. Setapar, M. J. Kamaruddin and M. A. C. Yunus, Energy Procedia, 2014, 61, 2572-2575.

15 G. Zhang, T. Wan, F. Gao and S. Dong, Chin. J. Chem. Eng., 2014, 22, 469-473.

16 F. Suanon, Q. Sun, B. Dimon, D. Mama and C. P. Yu, J. Environ. Manage., 2015, 166, 341-347.

17 O. Hanay, H. Hasar and N. N. Kocer, J. Hazard. Mater., 2009, 169, 703-710.

18 X. Zhang, Y. Tian, Q. Wang, L. Chen and X. Wang, Bioresour. Technol., 2012, 126, 41-47.

19 Y. Liu, J. Chen, Z. Cai, R. Chen, Q. Sun and M. Sun, Chem. Eng. J., 2017, 307, 1008-1016.

20 M. Bahemmat, M. Farahbakhsh and M. Kianirad, J. Hazard. Mater., 2016, 312, 307-318.

21 D. Kulikowska, Z. M. Gusiatin, K. Bułkowska and B. Klik, J. Hazard. Mater., 2015, 300, 882-891.

22 Z. Huang, Q. Wu, S. Liu, T. Liu and B. Zhang, Carbohydr. Polym., 2013, 97, 496-501.

23 Y. S. Açıkel, Use of Biosurfactants in the Removal of Heavy Metal Ions from Soils, Springer, Netherlands, 2011, vol. 20, pp. 183-223.

24 D. Kołodyńska, Desalination, 2011, 267, 175-183.

25 L. Gao, N. Kano, Y. Sato, C. Li, S. Zhang and H. Imaizumi, Bioinorg. Chem. Appl., 2012, 1-11.

26 S. Ozturk, T. Kaya, B. Aslim and S. Tan, J. Hazard. Mater., 2012, 231-232, 64-69.

27 S. Wang and C. N. Mulligan, Process Biochem., 2009, 44, 296301.

28 J. P. Maity, Y. M. Huang, C. M. Hsu, C. I. Wu, C. C. Chen, C. Y. Li, J. S. Jean, Y. F. Chang and C. Y. Chen, Chemosphere, 2013, 92, 1286-1293.

29 W.-C. Chen, R.-S. Juang and Y.-H. Wei, Biochem. Eng. J., 2015, 103, 158-169.

30 A. Popenda and M. Włodarczyk-Makuła, Desalin. Water Treat., 2015, 57, 1255-1261.

31 M. Ye, M. Sun, J. Wan, Y. Feng, Y. Zhao, D. Tian, F. Hu and X. Jiang, Ecotoxicol. Environ. Saf., 2016, 124, 344-350.

32 Z. M. Gusiatin and E. Klimiuk, Chemosphere, 2012, 86, 383391.

33 W. Zhou, J. Yang, L. Lou and L. Zhu, Environ. Pollut., 2011, 159, 1198-1204.

34 Z. M. Gusiatin, J. Environ. Sci., 2014, 26, 855-864.

35 W. Chen, L. Hsiao and K. Chen, Process Biochem., 2008, 43, 488-498.

36 S. Mitra and S. R. Dungan., J. Agric. Food Chem., 1997, 15871595.

37 M. A. Stylianou, D. Kollia, K.-J. Haralambous, V. J. Inglezakis, K. G. Moustakas and M. D. Loizidou, Desalination, 2007, 215, 73-81.

38 J. P. Maity, Y. M. Huang, C.-W. Fan, C.-C. Chen, C.-Y. Li, C.-M. Hsu, Y.-F. Chang, C.-I. Wu, C.-Y. Chen and J.-S. Jean, J. Environ. Sci., 2013, 25, 1180-1185. 
39 J.-y. Liu and S.-y. Sun, Trans. Nonferrous Met. Soc. China, 2013, 23, 2397-2407.

40 R. J. Meulepas, G. Gonzalez-Gil, F. M. Teshager, A. Witharana, P. E. Saikaly and P. N. Lens, Sci. Total Environ., 2015, 514, 60-67.

41 Q. Q. Zhu and Z. Zhang, Acta Sci. Circumstantiae, 2010, 30, 2491-2498.

42 P. Das, S. Mukherjee and R. Sen, Bioresour. Technol., 2009, 100, 4887-4890.

43 E. Peruzzi, G. Masciandaro, C. Macci, S. Doni, S. G. M. Ravelo, P. Peruzzi and B. Ceccanti, Ecol. Eng., 2011, 37, 771-778.

44 R. Li, W. Zhao, Y. Li, W. Wang and X. Zhu, J. Hazard. Mater., 2015, 283, 423-431.

45 E. Grygo-Szymanko, A. Tobiasz and S. Walas, TrAC, Trends Anal. Chem., 2016, 80, 112-124.

46 F. J. Ochoa-Loza, J. F. Artiola and R. M. Maier, J. Environ. Qual., 2001, 30(2), 479-485.

47 L. Wang, Z. Zheng, Y. Zhang, J. Chao, Y. Gao, X. Luo and J. Zhang, J. Hazard. Mater., 2013, 244-245, 1-9.

48 G. Xu, M. Liu and G. Li, J. Hazard. Mater., 2013, 260, 74-81.

49 M. Kuczajowska-Zadrożna, U. Filipkowska and T. Jóźwiak, Arch. Environ. Prot., 2015, 41(1), 47-56.

50 M. Cao, Y. Hu, Q. Sun, L. Wang, J. Chen and X. Lu, Environ. Pollut., 2013, 174, 93-99.

51 F. X. Han, A. Banin, W. L. Kingery, G. B. Triplett, L. X. Zhou, S. J. Zheng and W. X. Ding, Adv. Environ. Res., 2003, 8, 113120.
52 B. González-Corrochano, J. Alonso-Azcárate, L. Rodríguez, A. P. Lorenzo, M. F. Torío, J. J. T. Ramos, M. D. Corvinos and C. Muro, Constr. Build. Mater., 2016, 116, 252-262.

53 X. Yang, G. Xu, H. Yu and Z. Zhang, Bioresour. Technol., 2016, 211, 566-573.

54 D. Gola, P. Dey, A. Bhattacharya, A. Mishra, A. Malik, M. Namburath and S. Z. Ahammad, Bioresour. Technol., 2016, 218, 388-396.

55 B.-W. Pang, C.-H. Jiang, M. Yeung, Y. Ouyang and J. Xi, J. Hazard. Mater., 2017, 324, 732-738.

56 N. Li, D. Wei, S. Wang, L. Hu, W. Xu, B. Du and Q. Wei, J. Colloid Interface Sci., 2017, 490, 754-761.

57 E. Pantazopoulou, O. Zebiliadou, M. Mitrakas and A. Zouboulis, J. Waste Manage., 2017, 61, 327-336.

58 T. Wang, Y. Xue, M. Zhou, Y. Yuan, S. Zhao, G. Tan, X. Zhou, J. Geng, S. Wu and H. Hou, Chemosphere, 2017, 169, 162-170.

59 S. Li, Y. Pi, M. Bao, C. Zhang, D. Zhao, Y. Li, P. Sun and J. Lu, Mar. Pollut. Bull., 2015, 101, 219-225.

60 S. Song, L. Zhu and W. Zhou, Environ. Pollut., 2008, 156, 1368-1370.

61 E. Abbasi-Garravand and C. N. Mulligan, Sep. Purif. Technol., 2014, 132, 505-512.

62 J. M. Luna, R. D. Rufino and L. A. Sarubbo, Process Saf. Environ. Prot., 2016, 102, 558-566.

63 G. Peng and G. Tian, Chem. Eng. J., 2010, 165, 388-394. 